\title{
Stock repurchases and treasury share sales: Do they stabilize price and enhance liquidity?
}

\author{
Amedeo De Cesari ${ }^{\mathrm{a}, *}$, Susanne Espenlaub ${ }^{\mathrm{b}}$, Arif Khurshed ${ }^{\mathrm{b}}$ \\ a Aston Business School, Aston Triangle, Birmingham, B4 7ET, UK \\ b Manchester Business School, Booth Street West, Manchester, M15 6PB, UK
}

\section{A R T I C L E I N F O}

\section{Article history:}

Received 18 February 2010

Received in revised form 4 August 2011

Accepted 5 August 2011

Available online 11 August 2011

\section{JEL classification:}

G12

G35

Keywords:

Repurchase

Liquidity

Price stabilization

Bid-ask spread

Variance

\begin{abstract}
A B S T R A C T
Can companies reduce the volatility and increase the liquidity of their stocks by trading them? In the context of the Italian stock market, where companies have far more leeway to sell as well as buy their own stocks than in the U.S., the answer is yes. We examine the effects of trading (open-market share repurchases and treasury shares sales) on liquidity (bid-ask spread) and volatility (return variance). Further, we examine the impact of shareholder approvals of repurchase programs on liquidity and volatility. We find clear evidence that trading increases liquidity and reduces volatility. These results are consistent with our analysis of the motives Italian companies give for making share repurchases.
\end{abstract}

(c) 2011 Elsevier B.V. All rights reserved.

\section{Introduction}

Italian companies often repurchase shares with the stated objective of improving the liquidity and price stability of their stock. This paper assesses whether and to what extent companies can contribute to a more liquid and stable market in their stocks by trading their own shares through open-market repurchases ${ }^{1}$ and open-market sales of previously repurchased shares. We focus on the Italian stock market where companies face comparatively few restrictions on their trading in own shares and are motivated to act as market makers in their own stocks. ${ }^{2}$ We show that, on average, companies that aim to enhance their stock's liquidity and price stability through open-market transactions can expect to achieve their objectives.

In an open-market repurchase, the firm can decide whether and when to buy its own stock. Italian companies may also flexibly sell previously repurchased shares in the market. ${ }^{3}$ Repurchase programs therefore constitute a valuable opportunity for the issuer

\footnotetext{
* Corresponding author at: Finance and Accounting Group, Aston Business School, Aston University, Aston Triangle, Birmingham B4 7ET, UK. Tel.: + 44 121 2043028; fax: + 441212044915.

E-mail address: a.decesari@aston.ac.uk (A. De Cesari).

1 There are different repurchase methods. An open market repurchase program consists of acquisitions by a company of its own shares directly in the stock market, like any other investor. This type of repurchase is the focus of this paper. Below the terms "repurchase" and "buyback" will be used to refer exclusively to an open market repurchase.

2 Compared to the U.S. regulatory framework, the Italian system allows firms much greater freedom to trade their own shares (see Section 2 below).

${ }^{3}$ Italy is not the only country where companies can re-sell previously repurchased treasury shares (see, for example, OICV-IOSCO, 2004). For example, shelfregistration in the U.S. is intended as a low-cost, flexible method for companies to sell own stock. However, a significant proportion of U.S. companies is not eligible for shelf registration. By comparison, in Italy all listed companies are free to re-sell own stock in the open market at transaction costs that are arguably lower than in equivalent U.S. shelf-registered offerings (see Section 2.2. below).
} 
to intervene in the market for its own shares, providing liquidity when it is lacking and stabilizing the stock's price in turbulent periods. ${ }^{4}$

Anecdotal evidence confirms the relevance of price stabilization and liquidity enhancing activities in Italian stock repurchases. To justify the newly approved buyback program, on March 26, 1997, Pirelli SpA's CEO Marco Tronchetti Provera explained that it would be carried out "...to stabilize the security." He added, "We have no intention to intervene if stock market prices are satisfactory” (ANSA - Agenzia Nazionale Stampa Associata). Similarly, on September 25, 2001, Biosearch Italia SpA's CFO Ermenegildo Beghè claimed that one of the goals of their new buyback program was “... to use this instrument to reduce the volatility of the stock and support volume..." (Reuters). ${ }^{5}$

These are not rare statements in the Italian financial market. As we report in this paper, in approximately 40\% of repurchase program announcements during the period 1997-2004, the stated motives included the intention of the company to intervene in the secondary market for its own stock so as to reduce excess return volatility, to provide price support, and to increase liquidity.

Increasing a stock's liquidity can benefit the company and its owners in several ways. First, reducing the illiquidity costs borne by trading shareholders results in a lower cost of equity capital and increases firm value and shareholder wealth (Amihud and Mendelson, 1986; O'Hara, 2003). Second, increased liquidity increases the accuracy of the price signal and the efficiency of resource allocation based on the price signal. In turn, higher price accuracy can lead to lower asymmetric information costs of new issues (Myers and Majluf, 1984).

A priori it is unclear whether a company trading in its own shares reduces or increases liquidity. Barclay and Smith (1988) present two competing hypotheses. A company's repurchases of its stock may reduce liquidity because market makers find themselves trading with better informed company insiders (the "information asymmetry hypothesis"). On the other hand, a company's use of limit orders in purchasing its own stock may have the objective and the outcome of creating a deeper and broader order book (the "competing market maker hypothesis"). These arguments can also be applied to sales of previously repurchased treasury shares. The existing empirical evidence, discussed in greater detail below, is mixed (see, for example, Barclay and Smith, 1988; Singh et al., 1994; Cook et al., 2004). This study helps to resolve this important issue.

Turning to price stabilization, a smooth price discovery process with a minimum level of noise (Black, 1986) is a natural goal for a firm. Keeping noise and the resulting excess price volatility (Amihud and Mendelson, 1987; French and Roll, 1986) at a minimum level may reduce the impact of order imbalances caused by events such as liquidity shocks on observed prices. Price stabilization therefore helps firms ensure that their market price fully reflects the information available to investors on the market. A less noisy and more informative share price improves resource allocation. Also, both theoretical research (Levy, 1978; Merton, 1987) and empirical research (see, for example, Goyal and Santa-Clara, 2003) show that idiosyncratic risk affects security returns. If idiosyncratic risk is priced, lower excess volatility results in a lower risk premium and a lower cost of equity for the company. Whether firms can stabilize their market price through open-market trading is of considerable interest given the very limited empirical evidence to date (Brockman and Chung, 2001; Hong et al., 2008). Based on the previous literature and on the motives declared by Italian companies when initiating repurchase programs, we formulate two sets of competing hypotheses about the (direction of the) impact of trading on liquidity, proxied here by the bid-ask spread, and volatility, measured by return variance.

To test these hypotheses, we first collect a sample of firm-year observations on transactions in own shares carried out by repurchasing companies in the period 1997-2004. Through a series of univariate and multivariate analyses, we examine whether transactions in own shares have a significant effect on bid-ask spread and variance levels. Our findings show that trading reduces both bid-ask spreads and short-term return variance controlling for long-term, fundamental variance. This suggests that companies can use own-stock trading as an effective instrument to increase liquidity and reduce excess volatility or noise.

In a second, separate approach to assessing the impact of trading on spreads and volatility, we gather a sample of dates of annual general meetings of shareholders (AGMs) that approved repurchase programs in the 1997-2004 period. As a control group we use "non-approval" AGMs, i.e., dates of AGMs that did not authorize repurchase programs. We run a series of univariate and multivariate tests to compare changes in bid-ask spread and return variance around repurchase AGMs with similar variation around non-repurchase AGMs. Our findings indicate that there is a significant decrease in bid-ask spreads around buyback approvals. This effect is stronger for stocks with high spreads in the pre-AGM period. Similarly, controlling for long-term variance, there is a decrease in short-term variance around repurchase approval dates.

In conclusion, repurchase activities seem to have the potential to improve market quality. ${ }^{6}$ Our paper shows that repurchasing has a positive effect on liquidity, by reducing spread, and on price discovery, by lowering short-term excess volatility (variance).

\footnotetext{
${ }^{4}$ In this paper, the terms "price stabilization" and "price support" are used interchangeably. There is some evidence that companies attempt to repurchase stock at undervalued prices (see, for example, Brav et al., 2005). We argue that subtle but significant differences exist between repurchases aimed at stabilizing stock prices and repurchases of undervalued stock. The main goal of price stabilization activities is to counteract temporary order imbalances, possibly caused by liquidity shocks (Hong et al., 2008), and facilitate the price discovery process. When liquidity is low, an excess of selling orders can cause stock prices to fall by a significant amount. In this scenario, companies can step in, purchase own stock, and support stock prices. The price stabilization activities of issuers are akin to those of market makers and, as such, are not necessarily driven by the existence of inside information to be exploited. In contrast, companies may sometimes attempt to take advantage of inside information to identify windows of opportunity to buy back own stock at undervalued prices. Further, when companies undertake price stabilization activities they may want their transactions to have significant impact on stock prices. On the other hand, profits from purchases of undervalued stock can be maximized by reducing the impact of transactions on stock prices.

${ }^{5}$ The news reports mentioned in this paragraph were published by well-known Italian and international news agencies. The citations of executives' statements are the result of the authors' translation from Italian into English.

${ }^{6}$ Market quality is a concept with many facets. A comprehensive discussion of what market quality may mean in the market microstructure literature is presented by Schwartz and Francioni (2004), chapter 4.
} 
This result is of particular importance for policy makers as it shows that trading in own shares carries some significant benefits. Ownstock trading may lower transaction costs and costs of equity, and increase firm value and shareholders' wealth. When setting rules, policy makers should weigh such benefits against the potential social costs of well-informed insiders trading in own stock.

The paper is organized as follows. In Section 2 we provide a comparison of the institutional settings in Italy and the U.S. Associated with this section is our analysis of the motives stated by Italian companies announcing repurchase programs. Section 3 reviews the existing literature and presents our main hypotheses. We describe our data and methodology in Section 4 . The empirical findings are discussed in Section 5. A wide range of robustness checks is reported in Section 6. Section 7 concludes the paper.

\section{Share buybacks and treasury share sales in Italy and the U.S.}

\subsection{General regulatory differences}

Italian and U.S. share buyback programs differ in terms of regulations. In Italy, repurchase programs are first approved by directors and then formally authorized by a meeting of shareholders. A repurchase program can lead to the repurchase of up to $10 \%$ of the number of fully paid shares and can last for a maximum of 18 months (Article No. 2,357 of the Italian Civil Code). ${ }^{7}$ Approvals of Italian repurchase programs are clustered in that they generally take place between April and June. ${ }^{8}$ In contrast U.S. buyback programs are authorized by the board of directors, usually have no time limit, and may be suspended for periods or discontinued by the board of directors.

When repurchasing shares, companies are subject to insider trading and stock market manipulation regulations (see, for example, Fried, 2005). These regulations influence repurchase activities. The U.S. introduced a regulatory "safe harbor" protecting repurchasing companies from liability for stock manipulation practices in 1982. By contrast, safe-harbor laws were introduced in Italy only in 2005 as a result of the European Union Market Abuse Directive. Several studies (see, for example, Grullon and Michaely, 2002) relate the surge in U.S. share repurchases in the mid-1980s to the introduction in 1982 of the "safe harbor" rule. This evidence suggests that companies may refrain from repurchasing shares when in fear of breaching the law. Hence, less prohibitive insider trading and stock market manipulation regulations are probably associated with more intense trading in own shares. In relation to insider trading, Beny (2005) shows that the Italian regulation is less restrictive, especially in terms of enforcement, than the U.S. counterpart. Given that Italy ranks lower than the U.S. in terms of "rule of law" and "efficiency of judicial system" (see, for example, La Porta et al., 1998), it is also likely that Italian stock manipulation regulations are less strict and enforceable than U.S. regulations. Taken together, insider trading and stock manipulation regulations appear to be a greater impediment to repurchase activities in the U.S. than in Italy, and as a result, insider trading and stock manipulation are probably more likely to occur in Italy than in the U.S. ${ }^{9}$

\subsection{Rules on sales of treasury shares}

Italian companies enjoy substantial freedom in trading own shares. They can sell treasury shares that were previously bought back in the open market as long as sales of treasury shares have been authorized by shareholders (Pozzo, 2003, pp. 521-523). In most cases, when approving a repurchase program, Italian shareholders also authorize their directors and/or managers to sell treasury shares in the open market over the length of the program. Hence, in an Italian buyback program companies typically have the authority to repeatedly purchase own securities and sell them back in the open market without any formal procedures.

In the U.S., by contrast, treasury shares can only be sold back in the open market following all the formalities prescribed for offers of shares to the general public (OICV-IOSCO, 2004). ${ }^{10}$ The most flexible method for U.S. companies to sell treasury shares is through shelf-registered offerings. ${ }^{11}$ Although shelf registrations are intended to allow U.S. companies to issue stock flexibly and at comparatively low cost, we argue the Italian regime of treasury stock sales is even less restrictive and costly. Italian companies can execute sales of previously repurchased stock without any formalities such as registering these transactions in advance with the Consob. ${ }^{12}$ In contrast, U.S. companies are obliged to file (shelf-) registration statements with the SEC in order to sell stock to the public. In fact, a substantial proportion of U.S. companies are barred from using shelf registrations because they fail to meet the

\footnotetext{
7 According to Article No. 2,357, if companies repurchase more than $10 \%$ of fully paid shares, the excess shares must be resold or cancelled within 12 months. Cancellations of previously repurchased shares are quite rare in Italy. For example, in the sample with 788 firm-year observations that are used in some of the multivariate analyses of this study we only find four cancellations of common shares and three cancellations of other types of shares.

${ }^{8}$ In our sample, around 93\% of the repurchase approvals by annual general meetings of shareholders took place between April and June.

${ }^{9}$ We thank the anonymous referee for pointing out this caveat. It is not clear whether or how the comparatively high likelihood of insider trading and stock manipulation affects our results. We assume that it induces an unsystematic measurement error.

${ }^{10}$ We thank Jesse Fried and Jaemin Kim for helpful comments on this issue.

11 In a shelf registration, a company files a prospectus with the SEC in which it specifies the securities that could be issued in the future two years and the maximum dollar amounts of the issues. The registration does not oblige the company to issue securities, and the company can decide the timing of the issues. Over the years, the rules and procedures on shelf registrations were made less restrictive and more flexible. For instance, in 1992 the eligibility requirements were relaxed and smaller companies became eligible to use shelf-registered offerings (Autore et al., 2008). In 2005, the SEC introduced the so-called "automatic shelf registration" (Autore et al., 2011). This type of registration is open to "well known seasoned issuers" and allows their shelf registration statements to become effective immediately upon filing.

12 The Commissione Nazionale per le Società e la Borsa (Consob) is the public authority responsible for regulating the Italian securities markets with functions analogous to those of the SEC.
} 
criteria of eligibility. ${ }^{13}$ In Italy, by contrast, companies are not subject to eligibility criteria that limit their ability to sell treasury stock on the market. Finally, when selling treasury shares Italian companies resort to brokers like any other investor selling shares on the open market, and therefore face relatively low intermediation costs. U.S companies, by contrast, bear significant direct costs when selling stock even using shelf registrations because shelf-registered offerings are normally underwritten by financial institutions that charge significant underwriter fees. ${ }^{14}$

\subsection{Managerial motivations}

Italian and U.S. share buyback programs also differ in terms of motivations. The anecdotal evidence presented in the Introduction highlights the importance of price stabilization and increased liquidity in the minds of Italian executives in choosing to conduct share repurchases. In this study, we analyze the motives for repurchases as stated in 134 repurchase program announcements by Italian companies during the 1997 to 2004 period. We find that around $41 \%$ (92 out of 226) of the stated objectives in the repurchase announcements include intervening in the secondary market of a company's stock in order to reduce volatility, provide price support, and increase liquidity (see Table 1). Another commonly stated objective (in 49 cases out of 226 ) is the creation of reserves of treasury shares to fund incentive plans for managers and employees. In contrast survey evidence shows that American executives rarely mention liquidity and price stabilization as motives for buybacks (see, for example, Baker et al., 1981; Wansley et al., 1989; Brav et al., 2005). The difference between the U.S. and Italy may be due to U.S. executives' reluctance to state such aims explicitly for fear of sanctions from investors or regulators. It may also be the design of U.S. survey questionnaires that redirects answers away from potentially controversial, explicit statements on liquidity and stabilization to more roundabout answers that can be interpreted in various ways. For instance, Brav et al. (2005) report that chief financial officers claim to use share repurchases to buy undervalued stock; of course, such transactions may support stock prices and result in price stabilization.

\subsection{Market microstructure factors}

Over the sample period of the study, most stocks listed on the Italian Stock Exchange are negotiated through an electronic trading system based on continuous negotiation and a limit order book. Also, the limit orders submitted by traders to the electronic order book are normally the only source of liquidity and stock trading is generally not facilitated by the activities of designated market makers. $^{15}$

The trading system adopted in the Italian market is not uncommon in continental Europe and elsewhere but it is significantly different from that used by U.S. exchanges. In particular, market makers characterize in different ways both Nyse and Nasdaq (see, for example, Jain, 2003; Charitou and Panayides, 2009). Nyse is an order-driven market where the market for each stock is made by a specialist that provides liquidity and manages the limit order book of the stock. Nasdaq is a quote-driven market where trades must be negotiated through dealers.

Although the theoretical evidence on the benefits of market makers provides rather mixed findings (see, for example, Jain, 2003; Venkataraman and Waisburd, 2007), there is no lack of empirical support for the notion that market makers' activities boost liquidity. Jain (2003) studies a dataset of large stocks from 51 exchanges and finds that the presence of market makers is associated with higher liquidity. Nimalendran and Petrella (2003), Frino et al. (2008), and Perotti and Rindi (2010) show that the introduction of a specialist leads to higher liquidity in the Italian stock exchange. Also, improvements in market quality owing to the activities of market makers are found on the French (Venkataraman and Waisburd, 2007), Swedish (Anand et al., 2009), and Dutch (Menkveld and Wang, 2011) markets.

Companies can carry out trades in own shares to boost liquidity when it is lacking. In markets where designated market makers exist (i.e. the Nyse), repurchasing companies compete with these intermediaries and may provide additional liquidity. However, the trading activities of repurchasing companies are potentially more beneficial in markets like the Italian Stock Exchange where the endogenous liquidity offered by traders may sometimes be too low and market makers are normally absent. In these markets, issuers can increase trading in own shares when endogenous liquidity is low and, effectively, act as unique market makers.

To summarize, Italian companies are more likely than their U.S. counterparts to state liquidity and price stabilization as motives for share buybacks, and they enjoy a liberal regulatory setting allowing them to flexibly trade own shares. They are likely to be motivated to trade in own stocks in order to boost liquidity due to the absence of designated market makers for most Italian stocks.

\footnotetext{
13 In the period of our study, shelf-registered offerings were open to companies with a total market value of shares held by outsiders (i.e. free float) of at least $\$ 75$ million, that had complied with SEC disclosure obligations in the past year, had outstanding investment grade debt, and had not failed to honour their debt obligations in the past year (Autore et al., 2008; Moehrle et al., 2004). Autore et al. (2011) report that around one-third of U.S. listed companies were not eligible for shelf registrations due to the free float criterion alone.

${ }^{14}$ According to several recent estimates, average underwriter gross spreads for shelf registrations range from 3.88\% (Bethel and Krigman, 2008) to 3.99\% (Autore et al., 2008; this figure also includes other direct costs like legal fees paid by the issuer). There are also sizable indirect costs of selling stock through shelf registrations given that announcements of shelf registrations and of actual stock issues attract significant negative reactions by investors (see, for example, Bethel and Krigman, 2008; Gao and Ritter, 2010).

15 Based on information available on the website of the Italian Stock Exchange, we estimate that over the period 1997-2004 the average fraction of Italian shares that are obliged to have a designated market maker is $14.93 \%$. This fraction is zero in 1997 and gradually increases up to a level of $27.99 \%$ in 2004 . Specialists are compulsory for shares traded in Nuovo Mercato, a segment of the exchange created in 1999, and in the Star segment that was introduced in 2001.
} 
Table 1

Declared motives for open-market repurchases.

\begin{tabular}{|c|c|c|}
\hline The company launches the repurchase program & Observations & \% Frequency \\
\hline To carry out price stabilization, liquidity support, and similar activities in the secondary market & 92 & 41 \\
\hline To gather own shares necessary for incentive plans for managers and employees & 49 & 22 \\
\hline To gather own shares necessary to finalize future strategic transactions & 46 & 20 \\
\hline To invest free cash flow in own shares & 13 & 6 \\
\hline To signal the intrinsic value of the company & 9 & 4 \\
\hline To distribute free cash flow & 3 & 1 \\
\hline Other motives & 14 & 6 \\
\hline Total & 226 & 100 \\
\hline
\end{tabular}

Declared motives from company representatives for 134 repurchase programs approved in the period 1997-2004 by annual general meetings of Italian companies listed in the Italian stock market. The motives are inferred from the content of newspaper articles and news reports from news agencies. The repurchase programs are found through a key-word search on Factiva, targeting the 386 Italian listed companies in the sample period. Out of the 457 programs found, 323 programs are discarded because their motives cannot be found, bringing the final sample to 134 programs. 226 declared motives are found for this set of 134 repurchase programs. There are more motives than programs because some programs are justified by several motives. In the table, the first column offers a brief description of groups of declared motives, the second shows the number of observations for each group, and the third includes percent frequencies.

Given the motivation and the scope for companies to act as (competing) market makers, the Italian stock market appears to be a suitable setting in which to examine whether companies can affect stock liquidity and price stability by trading their own stock.

\section{Literature review and hypotheses}

The first formal study to raise the issue of the relationship between liquidity and buybacks is Barclay and Smith (1988). They assert that repurchases can cause liquidity reductions (the "information asymmetry hypothesis"). They argue that the presence of the company, which is a well-informed trader, can increase the adverse selection costs borne by institutional market makers or liquidity providers of trading with a better informed player. To compensate for these costs, market makers and liquidity providers increase the bid-ask spread, reducing liquidity (Bagehot, 1971; Glosten and Milgrom, 1985). Barclay and Smith also argue that liquidity may improve as a result of the presence of a repurchasing firm because the repurchasing firm represents a type of market maker who competes with the existing market makers and investors (the "competing market maker hypothesis"). The information asymmetry and competing market maker hypotheses are not mutually exclusive and may simultaneously affect liquidity, but in opposite directions. Moreover, these hypotheses may also explain the relation between sales of own shares and liquidity given that Barclay and Smith's (1988) arguments can easily be applied to these transactions.

The evidence on the effects of repurchases on liquidity is mixed. The findings of Barclay and Smith (1988) support the argument that a buyback reduces liquidity. Singh et al. (1994), Wiggins (1994), and Kim (2005) reject this argument although they do not find that repurchases improve liquidity. By contrast, Miller and McConnell (1995), Franz et al. (1995), Ahn et al. (2001), Cook et al. (2004), Eberhart and Siddique (2004), and Nayar et al. (2008) find that a buyback can make a stock more liquid. Outside the U.S., Brockman and Chung (2001) analyze a set of repurchases in Hong Kong and present evidence in support of the information asymmetry hypothesis.

The most widely used liquidity measure in finance (see, for example, Barclay and Smith, 1988; Miller and McConnell, 1995) is the spread between an asset's bid and ask quotes, known as the bid-ask spread. The higher the spread, the less liquid a market. We use the bid-ask spread to measure the liquidity of a company's stock.

Given the two rival hypotheses of Barclay and Smith (1988) and the mixed empirical evidence, our prediction on the relation between share repurchases or sales and liquidity is ambiguous. Therefore, we formulate the following two competing hypotheses (in alternative form):

Hypothesis 1a. Open-market repurchases or sales of own stock increase the liquidity (reduce the spread) of the stock.

Hypothesis 1b. Open-market repurchases or sales of own stock decrease the liquidity (increase the spread) of the stock.

An interesting analytical model of price stabilization by the company is presented by Hong et al. (2008). The main assumption of the model is that companies are willing to intervene in the market for their own stock, repurchasing or issuing (selling) own shares, when there is a discrepancy between stock prices and their fundamental values owing to liquidity shocks. ${ }^{16}$ In particular, companies carry out repurchases when their stock is undervalued, acting as "buyers of last resort," and issue shares when it is overvalued. To simplify the analysis of the model, Hong et al. (2008) further assume that companies can only intervene through repurchases. They clarify that this assumption is not critical to the results of the model. Hong et al. (2008) show that repurchases of underpriced shares have the effect of supporting a stock's price and reducing discrepancies between market and fundamental

\footnotetext{
16 In Hong et al.'s (2008) model, there is no consideration for the possibility that companies may use inside information to purchase undervalued own stock. An implicit assumption of the model is that a stock's fundamental value is known by all market participants, and differences between market prices and fundamental values are only caused by liquidity shocks.
} 
values. Hence, the main prediction of their model is that firms that are more capable of acting as buyers of last resort through share repurchases, i.e., firms that are less financially constrained have a less noisy stock price. Less noise implies lower short-term volatility for a given level of long-term or fundamental volatility. Using data on U.S. buybacks, Hong et al. (2008) offer empirical support for the prediction of their model. They also analyze a sample of non-U.S. firms, including Italian firms, to test this prediction but they do not use detailed firm-level data on share repurchases. Instead, they use proxies for financial constraints and assume that these proxies are related to aggregate repurchase activity.

Apart from Hong et al.'s (2008) findings, there is very little evidence on price stabilization. Cook et al. (2003) analyze a dataset of privately disclosed repurchase transactions. They find that corporations are more willing to run the risk of being subjected to price manipulation charges (owing to violations of SEC "safe harbor" Rule 10b-18) if transactions in own securities are likely to have the effect of reversing a drop in the price of their shares, i.e., of supporting the price of their shares. Using the same unique dataset, Cook et al. (2004) find that firms often buy their own stock after price drops and that these transactions produce shortterm price stabilization. Similarly, evidence from Hong Kong (Brockman and Chung, 2001) shows that companies usually buy back shares in periods when they are undervalued.

Based on the predictions of Hong et al. (2008), we formulate the following hypothesis (in alternative form):

Hypothesis 2a. Controlling for long- term or fundamental variance, open-market repurchases or sales of own stock reduce short-term return variance.

The conclusion of Hong et al. (2008) that repurchases and sales of own shares decrease short-term volatility may seem surprising. Transactions in own shares are a form of insider trading because companies can exploit inside information when carrying out these transactions. Hence, transactions in own shares and insider trading may have similar effects on short-term volatility. Leland (1992) argues that an increase in informed trading makes returns more volatile in the short term. When informed investors are present in the market, uninformed investors tend to trade following price changes triggered by random shocks in the belief that these changes are caused by informed trading and convey information. Fishman and Hagerty (1992) point out that insider trading could reduce price accuracy by deterring traders who are not insiders from acquiring information and trading. Finally, Du and Wei (2004) find that countries where insider trading is more pervasive are also characterized by more volatile stock prices.

In light of this literature, we formulate the following competing hypothesis (also in alternative form):

Hypothesis 2b. Controlling for long-term or fundamental variance, open-market repurchases or sales of own stock increase short-term return variance.

\section{Data and methodology}

Our aim is to assess the impact of trading in own shares on the liquidity and volatility of a company's stock. However, Italian companies do not disclose trading in their own shares at the time of the transaction. We use two separate research approaches designed to overcome this limitation. The first approach assesses the impact of trading by comparing the yearly averages of spread and volatility between firm-years (fiscal years) in which companies trade their own shares and firm-years without such transactions. We can identify trading of own shares because Italian companies are required to disclose all transactions in their own shares in their annual reports. ${ }^{17}$

Our second approach uses the fact that Italian companies require shareholder approval for stock repurchase programs. We identify annual general meetings at which shareholders approved repurchase programs ("approval" AGMs) and examine spread and volatility levels around approval and "non-approval" AGMs.

\subsection{Trading in own shares}

During the sample period 1997-2004 we identify a population of 386 Italian companies listed on the Italian stock exchange. ${ }^{18}$ From the annual reports of these firms, we collect the number of ordinary shares each company purchased and the number of treasury shares it sold in the open market in a given fiscal year. ${ }^{19}$

During our sample period, Italian companies were required to disclose both purchases of own shares and sales of previously repurchased shares in their annual reports (Article No. 2428 of the Italian Civil Code). In practice, we find that companies typically report sales of treasury shares alongside repurchases in the same "Repurchases" section of their annual reports. As our dataset comprises detailed hand-collected data on the annual number of common shares purchased and sold on the open market, it is free from the measurement biases in the pre-2004 U.S. repurchase data highlighted by Stephens and Weisbach (1998).

\footnotetext{
${ }^{17}$ As prescribed by Article No. 2428 of the Italian Civil Code, directors' reports included in companies' annual reports must provide information about transactions in own shares. The article specifies that companies must disclose in the directors' reports the number and nominal value of the own shares purchased and/or sold during the fiscal year.

${ }^{18}$ We only consider "SPA" and "SAPA" companies. A "SPA" is a typical limited company and most listed firms are in this category. A "SAPA" (only one in our sample) is a company in which only a subgroup of shareholders have limited liability. We exclude "SCRL" companies, cooperative firms that can potentially repurchase their stock, but are governed by a different regulatory framework than "SPA" and "SAPA" companies. The listed "SCRL" companies we exclude are commercial banks.

${ }^{19}$ Since April 2006, Italian companies have been additionally required to disclose detailed daily data on repurchase activity through monthly Consob filings. Consob is the Italian regulator analogous to the SEC.
} 
Table 2

Variable descriptions.

\begin{tabular}{|c|c|}
\hline Variable & Description \\
\hline TRADING & Ratio of the total number of own shares purchased or sold in a fiscal year to the number of outstanding shares at the end of the year. \\
\hline DUMMY TRADING & Dummy variable that is equal to one if TRADING is positive and zero otherwise. \\
\hline SPREAD & $\begin{array}{l}\text { Average daily, relative bid-ask spread computed using all the observations in a fiscal year. Relative bid-ask spread is the difference } \\
\text { between the ask and bid prices divided by the average of the two prices (in } € \text { ). This ratio is measured in decimals (not as a percentage). }\end{array}$ \\
\hline VARIANCE & $\begin{array}{l}\text { Daily return variance computed using all the observations in a fiscal year. This variable is the sample variance of daily log-returns } \\
\text { computed using daily closing prices. }\end{array}$ \\
\hline VOLUME & $\begin{array}{l}\text { Average daily trading volume computed using all the observations in a fiscal year. Trading volume represents the number of shares } \\
\text { traded in the market divided by the total number of outstanding shares. }\end{array}$ \\
\hline MARKET VALUE & Average daily market value (in billions of $€$ ) computed using all the observations in a fiscal year. \\
\hline PRICE & Average daily closing price (in $€$ ) computed using all the observations in a fiscal year. \\
\hline RETURN & Average daily log-return computed using all the observations in a fiscal year. Daily log-return is calculated using daily closing prices. \\
\hline $\begin{array}{r}\text { LONG TERM } \\
\text { VARIANCE }\end{array}$ & $\begin{array}{l}\text { Long-term return variance computed using all the observations in a fiscal year. In computing this variable, log-returns for periods of } \\
\text { four weeks, six weeks, or eight weeks are used. The long-term variance is properly scaled in order to make it comparable with the daily } \\
\text { variance (for example, the six-week variance is divided by 30). Closing prices are used to calculate log-returns. }\end{array}$ \\
\hline MARKET SPREAD & $\begin{array}{l}\text { Average daily, relative, value-weighted market bid-ask spread computed using all the observations in a fiscal year. For stock } i \text { and day } t \text {, } \\
\text { the value-weighted market bid-ask spread is computed using daily data on market value and bid-ask spread on day } t \text { for all the } \\
\text { securities in the sample except stock } i \text {. }\end{array}$ \\
\hline MARKET VARIANCE & $\begin{array}{l}\text { Value-weighted market daily return variance computed using all the observations in a fiscal year. For stock } i \text {, the value-weighted } \\
\text { market daily return variance is computed using data on daily return variance and average daily market value for all the securities in the } \\
\text { sample except stock } i \text {. }\end{array}$ \\
\hline
\end{tabular}

Panel B: Dataset and variables for analysis of repurchase approvals

APPROVAL AGM Dummy variable that is equal to one when the observation relates to an annual general meeting (AGM) that approved a repurchase program and zero otherwise.

SPREAD CHANGE Natural logarithm of one plus the relative change in average daily, relative bid-ask spread around an annual general meeting (AGM) date (day 0 ). The relative change is the spread in the post-AGM event window (from trading day +11 to trading day +120 ) less the spread in the pre-AGM event window (from trading day - 120 to trading day -11) divided by the pre-AGM spread. Relative bid-ask spread is the difference between the ask and bid prices divided by the average of the two prices.

VARIANCE CHANGE Natural logarithm of one plus the relative change in daily return variance around an annual general meeting (AGM) date (day 0) computed as the daily return variance in the post-AGM window (from trading day +11 to trading day +120 ) less the variance in the pre-AGM window (from trading day -120 to trading day -11) divided by the pre-AGM variance. Return variance is the sample variance of the daily logarithmic returns computed using daily closing prices.

IPO Dummy variable coded one if at least one trading day belonging to the first year (253 trading days) of listing of the stock is within the interval of 120 trading days around the AGM, that is in the window (day -120 , day +120 ), and zero otherwise.

VOLUME CHANGE Natural logarithm of one plus the relative change in average daily trading volume around an annual general meeting (AGM) date (day 0 ). The relative change is the volume in the post-AGM event window (from trading day +11 to trading day +120 ) less the volume in the pre-AGM event window (from trading day -120 to trading day -11 ) divided by the pre-AGM volume. Trading volume is the number of shares traded divided by the number of outstanding shares.

PRICE CHANGE Natural logarithm of one plus the relative change in average daily closing price around an annual general meeting (AGM) date (day 0). The relative change is the price in the post-AGM event window (from trading day +11 to trading day +120 ) less the price in the preAGM event window (from trading day -120 to trading day -11) divided by the pre-AGM price.

LONG TERM Natural logarithm of one plus the relative change in long-term return variance around the AGM computed analogous to VARIANCE

VARIANCE CHANGE CHANGE but using the long-term return variance. The long-term return variance is the variance of the long-term returns in each of the two event windows (day -120 , day -10$)$ and (day +10 , day +120$)$. Long-term returns are computed using closing prices and are measured as logarithmic returns over the period of the event window observing prices at three alternative intervals, specifically at intervals of two, three, or four weeks.

MARKET SPREAD Natural logarithm of one plus the relative change in average daily value-weighted market bid-ask spread around an AGM. The relative CHANGE change is computed analogous to SPREAD CHANGE but using the average value-weighted market bid-ask spread instead of the spread of the individual stock. For stock $i$ and day $t$, the value-weighted market bid-ask spread is computed using daily data on market value and bid-ask spread on day $t$ for all the securities in the sample except stock $i$.

MARKET VARIANCE Natural logarithm of one plus the relative change in value-weighted market variance of daily returns around the AGM. The relative change is CHANGE computed analogous to VARIANCE CHANGE but using the value-weighted market return variance. For stock $i$ and for either the pre- or the post-AGM event window, the value-weighted market return variance is computed by weighting the return variances of all stocks except stock $i$ using as weights the averages of daily market value. Stock return variances are calculated for all the securities in the sample as the variances of daily logarithmic returns (based on closing prices) in each of the two event windows (pre- and post-AGM).

Descriptions of the dependent and independent variables used in the empirical analyses of the dataset of trading in own shares (Panel A) and of the dataset of approvals of repurchase programs (Panel B). Data are collected from Thomson Datastream, Factiva and company annual reports.

Research on U.S. repurchases was hampered by limited disclosure of repurchase transactions prior to 2004. As a result studies relied on imperfect measures of firms' repurchase activities. Stephens and Weisbach note that for transactions prior to 2004 “... share repurchases can be neither observed at the time the transaction occurs nor directly measured afterward” (p. 318). ${ }^{20}$

\footnotetext{
20 They evaluate four frequently used U.S. measures of the number of common shares repurchased: the monthly decrease in shares outstanding from the Center for Research in Security Prices (CRSP), the quarterly decrease in shares outstanding from Compustat, the dollars spent purchasing common and preferred stock from Compustat, and the increase in treasury stock from Compustat.
} 
Stephens and Weisbach argue that these measures provide overstated or understated estimates of the number of repurchased common shares. Since January 2004 U.S. listed firms are required to disclose information on their monthly repurchase transactions in their SEC filings (10-Ks and 10-Qs). A growing number of researchers are taking advantage of this new data source (see, for example, Banyi et al., 2008). Nevertheless, the specific disclosure requirement still leaves scope for improvement, and extracting accurate measures of open-market repurchasing is in some cases still impossible (De Cesari et al., 2011). ${ }^{21}$

Financial data on stock closing price, return, closing bid and ask prices, trading volume, market value, and number of outstanding shares are collected from Thomson Datastream. ${ }^{22}$

We start with an initial sample of firm-year observations in the period 1997-2004 of 1853 firm-years each with a duration of 12 months (after excluding shorter financial years and incomplete financial years starting before January 1997 or ending after December 2004). From this we exclude 232 firm-years that are contaminated by the following capitalization changes: stock splits, reverse stock splits, stock dividends, rights issues, extraordinary dividends, one-off distributions of equity capital, issues of convertible bonds and warrants, and demergers. ${ }^{23}$ Next we exclude observations with missing or incomplete data on trading in own shares or on other variables. The final sample comprises 1365 firm-year observations across 317 companies. Of these 152 companies carried out transactions in their own shares in 422 of our sample firm-years; in the remaining 943 firm-years, no such transactions took place.

We formally evaluate the representativeness of this regression sub-sample by comparing the means and medians of our variables in this sub-sample with those for the excluded observations (wherever data is available). The findings are discussed below in Section 5.1.

We use the non-parametric Mann-Whitney test to compare distributions. The Mann-Whitney test is frequently referred to as a "test of medians" (including in some parts of this paper below). However, it is formally a test that compares two distributions. Specifically, it tests whether one distribution is stochastically greater than another. If the only possible difference between the two distributions is a location shift (i.e. the values of one distribution are equal to the values of the other plus a fixed number), then the Mann-Whitney test is indeed a test of the difference between the two medians. Otherwise, it is possible for the test to indicate a statistically significant difference between the distributions even when the difference between the two medians is small.

To test whether spread and volatility are systematically affected by own-share trading, we compare average levels of spread and volatility in years in which own shares were traded with averages in years without transactions in own shares. We compute SPREAD as the simple average across the daily observations of relative spread for each trading day in a calendar year. For example, if a firm-year has 250 trading days, we average the 250 daily relative spread observations. Our volatility measure, VARIANCE, is calculated for each firm-year as the variance of the 250 daily log-returns in that year. More details on the definition, calculation, and data sources of SPREAD, VARIANCE, and the other variables described below can be found in Table 2 (Panel A).

Next, we conduct multivariate analyses to identify whether trading in own shares is a determinant of SPREAD and VARIANCE after controlling for other factors. ${ }^{24}$ The two crucial explanatory variables in the models are TRADING, the number of own shares bought plus the number sold in each fiscal firm-year divided by the number of outstanding shares at year-end, and DUMMY TRADING, which takes the value of one if TRADING is positive, and zero otherwise. By analyzing the coefficients on these two explanatory variables we test the direction and significance of the impact of trading in own shares on the dependent variables SPREAD and VARIANCE. In order to identify any systematic effects of trading in own shares on the dependent variables, we must control for any pre-existing differences between trading and non-trading firms. For instance, firms may have higher propensities to trade their shares in years when the spread or volatility of their stocks is unusually low or high. ${ }^{25}$ Therefore, comparisons of the spreads and variances of trading and non-trading companies may show spurious associations between transactions in own shares and lower-than-usual levels of spread or volatility even if trading in own shares has no impact on spread and volatility. To account for the likelihood that trading in own shares is endogenous, i.e., that it is both a determinant and a function of spread and volatility, we estimate regression models of SPREAD and VARIANCE using Generalized Method of Moments (GMM) in addition to Ordinary Least Squares (OLS) estimations. As instruments for the endogenous (DUMMY) TRADING variables we use the lagged values (observed at the end of the previous year) of operating and non-operating income scaled by total assets. ${ }^{26,27}$ Highly profitable firms are particularly likely to carry out share repurchases (see, for example, Skinner, 2008) and there is evidence that repurchases

\footnotetext{
21 Computing the exact number of shares bought back on the open market in the U.S. (after January 2004) is still not always straightforward. As noted by De Cesari et al. (2011), off-market repurchases (e.g., repurchases through privately negotiated transactions and self-tender offers) are quite common, and separating these repurchases from those executed on the open market can often be difficult.

${ }^{22}$ Data are screened to eliminate non-trading days and treating observations when stocks are suspended as missing. Information on non-trading days and stock suspensions is gathered from the official website of the Italian Stock Exchange and Factiva.

${ }^{23}$ We find capitalization changes by noting variations in the factors used on Datastream and the Italian Association of Financial Analysts (AIAF; www.aiaf.it) to adjust the time series of the sample stocks. Details on the numbers of observations excluded due to the various screening criteria are available from the authors upon request.

${ }^{24}$ In Section 5, we estimate the SPREAD and VARIANCE equations independently, but in Section 6 we explicitly recognize that the two variables may be jointly determined.

${ }^{25}$ Brockman et al. (2008) show that companies with more liquid stocks are more likely to prefer repurchases over dividends and von Eije and Megginson (2008) find that liquidity is positively related to repurchase activity.

${ }^{26}$ As highlighted by Wooldridge (2002, p. 84), a crucial condition to have a valid instrumental variable is that the (partial) correlation between the instrument and the instrumented endogenous variable is different from zero. Wooldridge also points out that the validity of an instrument in light of the condition above is dependent neither on the distribution of the instrument nor on the distribution of the endogenous variable. In other words, a continuous variable such as operating income or non-operating income can be a valid instrument for the endogenous binary variable DUMMY TRADING.

27 Data for these instruments are collected from Worldscope. Total assets is item 02999 and operating income is item 01250. Non-operating income is the difference between net income (item 01706) and operating income.
} 
are strongly related to non-operating cash flows (see, for example, Jagannathan et al., 2000). Given that repurchases constitute the main component of the (DUMMY) TRADING variables, operating and non-operating income are valid instruments. ${ }^{28}$ We estimate various GMM regressions (as described below) always instrumenting (DUMMY) TRADING in the same way.

As we find spread and volatility to be persistent, we include in each model the lagged dependent variable to avoid misspecification biases. ${ }^{29}$ We estimate the models using OLS and GMM. In addition, to take into account the endogeneity of the lagged dependent variable we estimate two separate GMM models. First, we adopt the Arellano and Bond (1991) difference GMM method for dynamic panel data models using the second lag of the dependent variable (e.g., $S P R E A D(t-2))$ as the instrument for the first difference of the lagged dependent variable (e.g., SPREAD $(t-1)-S P R E A D(t-2)$ ). Second, we use the system GMM estimator of Arellano and Bover (1995) and Blundell and Bond (1998), which involves estimating a levels equation jointly with the difference equation. ${ }^{30}$ In the difference equation, the instrument for the first difference of the lagged dependent variable remains the second lag of the dependent variable as in the difference GMM method. At the same time, in the levels equation, the first difference of the lagged dependent variable (e.g., SPREAD $(t-1)-\operatorname{SPREAD}(t-2))$ is used as an instrument for the lagged dependent variable (e.g., SPREAD $(t-1)) .^{31}$

We include known determinants of bid-ask spread and volatility as control variables. The existing literature shows that stock return volatility, trading activity, market value, and stock price play a role in explaining variations in spread (see, for example, Demsetz, 1968; Tinic, 1972; Branch and Freed, 1977; Stoll, 1978; Stoll, 2000). Several quantitative analyses find that greater trading frictions (higher spreads) increase volatility (see, for example, Amihud and Mendelson, 1987; Kaul and Nimalendran, 1990; Koski, 1998; Wang and Yau, 2000), and report a positive correlation between trading volume and volatility (see, for example, Karpoff, 1987; Harris and Raviv, 1993; Shalen, 1993). There is also evidence on the impact of trading volume on volatility (see, for example, Schwert, 1989; Gallant et al., 1992; Lamourex and Lastrapes, 1990; Stoll and Whaley, 1990; Lee and Rui, 2002). Moreover, Duffee (1995) finds a positive contemporaneous relationship between return and return volatility. Therefore, the SPREAD model includes volatility (VARIANCE), average daily trading volume (VOLUME), average daily market value (MARKET $V A L U E)$, and average daily closing stock price (PRICE). Similarly, the VARIANCE regression includes SPREAD, VOLUME, and average daily return $(R E T U R N)$.

The VARIANCE model also controls for the long-term fundamental variance of the stock to separate long-term volatility related to fundamental factors from short-term volatility reflecting the effect of noise in line with the model and findings of Hong et al. (2008) and also with Hypotheses 2a and 2b. The variable LONG TERM VARIANCE is calculated using returns measured over four-, six-, and eight-week intervals.

There is also evidence that market-wide liquidity is a relevant determinant of the liquidity of individual stocks (Brockman and Chung, 2002; Chordia et al., 2000). Therefore, we include MARKET SPREAD. MARKET SPREAD for stock $i$ is calculated as the simple average of daily market spreads across all trading days in a given fiscal year, with the daily market spread for day $t$ and stock $i$ defined as the value-weighted average of the relative spreads of all stocks in the market on day $t$ with the exception of stock $i$. Analogously, the regression of VARIANCE includes a measure of market-wide volatility, MARKET VARIANCE. MARKET VARIANCE is the value-weighted average of the stock return variances (calculated using the daily logarithmic returns for all the trading days of a given fiscal year) on all the stocks in the market with the exception of stock $i$.

Finally, industry and year dummies are included but the coefficients are not reported.

\subsection{Shareholder approvals of repurchase programs}

Our second approach focuses on the impact of gaining shareholder approval for a share repurchase program at the company's annual general meetings on the spread and volatility of the company's stock. Italian companies require shareholder approval to conduct open-market repurchases and to sell any previously repurchased treasury shares in the open market. We analyze announcements of repurchase approvals because companies appear to focus on announcements of repurchase programs and treat announcements of sales approvals as less important, resulting in poor coverage of such announcements in our databases. Often we find sales announcements as mere by-lines in announcements dealing mainly with repurchase approval. In our sample of repurchase announcements, sales of treasury stock are often approved at the same time as repurchase programs.

For the population of 386 listed Italian companies we identify the dates of annual general meetings of shareholders and whether a repurchase program was approved or not using Factiva and annual company reports. For the sample period 1997-2004, we find 465 AGMs at which repurchases were approved. To control for the impact of seasonal patterns and confounding events and information releases associated with shareholder meetings, we use a control sample of 891 "non-repurchase" AGMs, i.e.,

\footnotetext{
${ }^{28}$ In the sample of 788 observations used in the regressions, we have 18 firm-year observations with sales and no purchases of own shares. This finding is not surprising since sales of own shares must be preceded by share repurchases. Also, the average value of the number of own shares purchased scaled by the number of outstanding shares is 0.004038 and the average value of the number of own shares sold scaled by the number of outstanding shares is 0.002195 . Based on these figures, $64.78 \%$ of the trading in own shares is represented by share repurchases.

29 The first-order autoregressive coefficient is 0.7621 ( $t$-stat of 36.11 ) for SPREAD and 0.43 ( $t$-stat of 12.57) for VARIANCE.

30 Bond (2002) and Roodman (2006) provide comprehensive explanations of both the difference GMM and the system GMM estimators. We use the Stata command xtabond2 to apply these estimators to our dataset. Applications of difference GMM and system GMM estimators in finance research have become quite common in recent years (see, for example, Mura, 2007; Lemmon et al., 2008).

31 For ease of exposition, the first columns of Tables 5 and 6 show the labels of the variables expressed in levels even for the models estimated using differences (i.e., the difference and system GMM models).
} 
shareholder meetings at which no repurchase program was approved. Overall, our sample comprises a total of 1356 observations, consisting of 465 repurchase and 891 non-repurchase AGMs, associated with 315 companies. $^{32}$

By comparing repurchase and non-repurchase AGMs, we test whether the changes in liquidity and volatility around the date of a shareholder meeting, day 0 , differ depending on whether a repurchase program was approved at the meeting. We evaluate changes in spread and volatility by comparing the averages of relative spreads and volatility during the pre-meeting period, days $(-120,-11)$, with the averages during the post-approval period, days $(+11,+120)$. The period $(-10,+10)$ is excluded to avoid results being influenced by short-term dynamics around day 0. For example, the change in spread is computed as the difference in average daily spreads between the post and pre-AGM periods divided by the pre-AGM average daily spread. This and similar variables are subject to a logarithmic transformation in order to reduce skewness and excess kurtosis and to apply standard test statistics relying on normality. More details on the definition, data sources, and construction of our variables are given in Table 2 (Panel B).

To assess the impact of repurchases, we use both univariate and multivariate analyses. We regress the dependent variables measuring changes around the AGM in spreads (SPREAD CHANGE) and volatility (VARIANCE CHANGE) against a dummy variable indicating whether the AGM approved a repurchase program (APPROVAL AGM).

As in the first approach, we include known determinants of spread and volatility as control variables. The SPREAD CHANGE regression includes changes in volatility (VARIANCE CHANGE), trading volume (VOLUME CHANGE), and stock price (PRICE CHANGE). Similarly, the VARIANCE CHANGE regression includes SPREAD CHANGE, VOLUME CHANGE, and PRICE CHANGE. The VARIANCE CHANGE regression also controls for changes in the long-term fundamental variance (LONG TERM VARIANCE CHANGE).

We also include changes in the market-wide spread and volatility, MARKET SPREAD CHANGE and MARKET VARIANCE CHANGE, respectively. These control variables are analogous to the dependent variables SPREAD CHANGE and VARIANCE CHANGE in terms of the computation of the changes around the AGM, and to the variables in the first part of our analysis in terms of data sources and the construction of the market-wide measures.

Finally, a dummy variable (IPO) serves to control for recent listings, and full sets of year and industry dummies are included (but coefficient estimates are not reported).

\section{Empirical findings}

Table 3 provides the descriptive statistics of the variables used in our first approach, while Tables 4 to 6 present the findings of our examination of the impact of trading in own stocks on the yearly averages of spread and variance. Table 7 gives descriptive statistics of the variables used in the second approach. The results of the impact of repurchase approvals at AGMs on spreads and volatility (variance) are provided in Tables 8 to 10.

\subsection{Effects of own-share trading on spread and volatility}

Panels A and B of Table 3 show descriptive statistics for the variables used in the first approach. Panel A is based on the full sample of 1365 observations, while Panel B reports figures for the sub-sample of 788 observations used in the regression analysis. ${ }^{33}$ In Panel A, the mean of TRADING (0.0059) shows that an average company trades $0.59 \%$ of its outstanding shares in a given financial year. The largest trading activity is $27.49 \%$, shown by Sabaf SpA in the year 2001. Nearly 31\% of the sample firmyears show positive trading in own shares. The average relative bid-ask spread is 0.016 or $1.6 \%$. The maximum bid-ask spread $(66.67 \%)$ is observed for Binda SpA, a company with a market capitalization of just $€ 31$ million, while the minimum bid-ask spread $(0.06 \%)$ relates to Assicurazioni Generali SpA, a large company with a market capitalization of €28 billion. Average volatility (VARIANCE) is 0.0006 or $0.06 \%$ with a maximum (minimum) of $3.27 \%(0.003 \%)$ in any firm-year. The average daily trading volume is $0.22 \%$. The firm-years show an average daily market value of $€ 1.75$ billion. The average long-term variance measured over periods of four, six, and eight weeks is around $0.07 \%$. The average market spread and variance are $0.91 \%$ and $0.05 \%$ respectively. The descriptive statistics of the variables used in the multivariate analyses are shown in Panel B. As can be seen from these statistics, the reduced sample is generally an appropriate sub set of the overall sample in terms of characteristics of the variables used in the study.

Table 4 reports descriptive statistics for two sub-samples, one for the 422 firm-years in which companies report purchases and/ or sales of own shares (so-called 'trading firm-years'), and another for 943 'non-trading firm-years' without such transactions. We report the findings of univariate tests of differences in means and medians in Panel A (using asterisks to indicate significance).

\footnotetext{
32 In total, we find announcements of 669 repurchase programs. We exclude observations with less than 120 trading days before and after the announcement (due to a recent listing or delisting), and those with multiple repurchase approvals or capitalization changes in the 120 days around the announcement. Capitalization changes are identified by noting variations in the factors used on Datastream and the Italian Association of Financial Analysts (AIAF; www.aiaf.it) to adjust the time series of the sample stocks. We also exclude 90 approval dates that coincided with extraordinary rather than annual general meetings. Further details are available from the authors upon request. The number of companies for which we observe AGMs (315) is lower than the population (386) due to missing data and data screening.

33 The estimation methods used below report 788 as the number of observations. This apparent loss of observations relative to the 1365 firm years used in the univariate analysis arises from the need to use some observations to create differences and lags in the GMM estimation methods. By comparing the distributions of included and excluded observations, we find that our reduced regression sub-sample comprises observations with on average higher stock liquidity and lower return volatility than the excluded observations. The implication of these findings is that we exclude observations for firms and years that, being less liquid and more volatile, should benefit comparatively more from transactions in own shares. By doing this, we arguably bias our analysis against finding significant results.
} 
Table 3

Descriptive statistics for full and reduced samples of firm-year observations.

\begin{tabular}{|c|c|c|c|c|c|c|c|}
\hline \multicolumn{8}{|c|}{ Panel A: Overall sample of observations (1,365 observations) } \\
\hline Variable & Mean & Median & Standard deviation & Maximum & Minimum & Skewness & Kurtosis \\
\hline TRADING & 0.0059 & 0 & 0.0182 & 0.2749 & 0 & 6.43 & 60.33 \\
\hline DUMMY TRADING & 0.3092 & - & - & - & - & - & - \\
\hline SPREAD & 0.016 & 0.0107 & 0.0239 & 0.6667 & 0.0006 & 15.9094 & 405.4629 \\
\hline VARIANCE & 0.0006 & 0.0005 & 0.001 & 0.0327 & 0.00003 & 22.5091 & 675.3283 \\
\hline VOLUME & 0.0022 & 0.0016 & 0.0023 & 0.0313 & 0.00005 & 3.7237 & 28.0269 \\
\hline MARKET VALUE (€ billion) & 1.745 & 0.2032 & 5.7518 & 67.8091 & 0.0038 & 6.8008 & 54.8007 \\
\hline $\operatorname{PRICE}(€)$ & 6.6855 & 3.2791 & 9.9931 & 140.7835 & 0.0123 & 4.7103 & 38.5343 \\
\hline RETURN & 0.00002 & 0.0001 & 0.0017 & 0.0084 & -0.0145 & -0.7918 & 5.6656 \\
\hline LONG TERM VARIANCE (4 weeks) & 0.0007 & 0.0004 & 0.0009 & 0.0106 & 0.00002 & 4.3079 & 26.6633 \\
\hline LONG TERM VARIANCE (6 weeks) & 0.0006 & 0.0004 & 0.0009 & 0.01 & 0.00001 & 4.4423 & 28.0461 \\
\hline LONG TERM VARIANCE (8 weeks) & 0.0007 & 0.0003 & 0.001 & 0.0153 & 0.00001 & 5.5707 & 49.8862 \\
\hline MARKET SPREAD & 0.0091 & 0.0054 & 0.0076 & 0.0355 & 0.0022 & 1.2061 & 0.1973 \\
\hline MARKET VARIANCE & 0.0005 & 0.0006 & 0.0002 & 0.0011 & 0.0001 & -0.3613 & -0.8477 \\
\hline \multicolumn{8}{|c|}{ Panel B: Reduced sample of observations used in the multivariate analyses ( 788 observations) } \\
\hline TRADING & 0.0062 & 0 & 0.0197 & 0.2749 & 0 & 6.6961 & 63.9477 \\
\hline DUMMY TRADING & 0.3185 & - & - & - & - & - & - \\
\hline SPREAD & 0.0153 & 0.0108 & 0.0162 & 0.1752 & 0.0006 & 3.9632 & 26.0559 \\
\hline VARIANCE & 0.0006 & 0.0005 & 0.0004 & 0.0046 & 0.00003 & 2.7967 & 14.7143 \\
\hline VOLUME & 0.0021 & 0.0015 & 0.0023 & 0.0313 & 0.00005 & 4.2389 & 40.2595 \\
\hline MARKET VALUE ( $€$ billion) & 1.8081 & 0.2088 & 5.6675 & 67.8091 & 0.0062 & 6.6922 & 54.8323 \\
\hline PRICE (€) & 5.9406 & 3.2266 & 7.5011 & 58.3262 & 0.053 & 2.7593 & 9.496 \\
\hline RETURN & 0.0001 & 0.0002 & 0.0014 & 0.0063 & -0.0065 & -0.3136 & 1.5561 \\
\hline LONG TERM VARIANCE (4 weeks) & 0.0006 & 0.0003 & 0.0007 & 0.0067 & 0.00002 & 3.574 & 19.2839 \\
\hline LONG TERM VARIANCE (6 weeks) & 0.0006 & 0.0003 & 0.0008 & 0.008 & 0.00001 & 4.7375 & 34.4393 \\
\hline LONG TERM VARIANCE (8 weeks) & 0.0006 & 0.0003 & 0.0008 & 0.0083 & 0.00001 & 3.9206 & 22.893 \\
\hline MARKET SPREAD & 0.0084 & 0.0049 & 0.0074 & 0.0355 & 0.0023 & 1.2477 & 0.1501 \\
\hline MARKET VARIANCE & 0.0005 & 0.0006 & 0.0002 & 0.0011 & 0.0001 & -0.306 & -1.1482 \\
\hline
\end{tabular}

Descriptive statistics relating to all the variables in the empirical analyses of two datasets of 1365 and 788 firm-year observations for Italian companies in the period 1997-2004. In the larger sample, there are 422 firm-years with positive trading in own shares and 943 firm-years with zero trading in own shares. The smaller sample is used in the multivariate analyses. Data on own share trading are taken from companies' annual reports. Data for the other variables are obtained from Thomson Datastream. TRADING is the ratio between the number of own shares bought or sold in a given financial year and the end-of-year number of outstanding shares. DUMMY TRADING is a dummy that equals one when TRADING is positive. For each firm-year, SPREAD, VARIANCE, VOLUME, MARKET VALUE, PRICE, RETURN, and LONG TERM VARIANCE are the average daily relative bid-ask spread, daily return variance, average daily trading volume, average daily market value (in billions), average daily closing price, average daily log-return, and long-term return variance, respectively. The long-term variance is calculated using four-week, six-week, or eight-week log-returns. MARKET SPREAD and MARKET VARIANCE are the average value-weighted market daily bid-ask spread and the value-weighted market daily return variance. All variables are described in detail in Table 2.

We find that SPREAD and VARIANCE are on average lower in trading firm-years than in non-trading firm-years consistent with Hypotheses 1a and 2a. In firm-years without own-share trading, the mean of SPREAD is $1.8 \%$, but in firm-years with trading it is only $1.1 \%$. This means that in trading firm-years, SPREAD is $39 \%$ lower than in non-trading firm-years. That is, the difference of 0.7 percentage points between trading and non-trading firm-years amounts to $39 \%$ of the 1.8 percentage point SPREAD in non-trading years. Similarly, VARIANCE is on average lower in firm-years with trading in own shares. In firm-years without own-share trading, the mean of VARIANCE is $0.07 \%$, but in firm-years with trading it is only $0.05 \%$. The difference in VARIANCE between trading and non-trading firm-years is 0.02 percentage points. This means that VARIANCE in trading firm-years is $29 \%$ lower than in non-trading firm-years (as the 0.02 percentage-point difference amounts to $29 \%$ of the value of VARIANCE in non-trading firm-years).

By comparison with the means, the differences in medians between trading and non-trading firm-years are smaller for both SPREAD and VARIANCE. The median SPREAD is $11.5 \%$ lower in trading firm-years (where the median is $1.00 \%$ ) than in non-trading firm-years (where the median is $1.13 \%$ ). VARIANCE is $20 \%$ lower in trading firm-years (at $0.04 \%$ ) than in non-trading firm-years (0.05\%).

Statistically, the differences between trading and non-trading firm-years in the means and medians of SPREAD and VARIANCE are highly significant (with $p$-values of $1 \%$ or much less). ${ }^{34}$ In Table 4 , we indicate the results of t-tests of the equality of means for unpaired samples next to the means, and the results of non-parametric Mann-Whitney tests next to the values of the medians in Panel A. As outlined in Section 4.1., the Mann-Whitney test is frequently referred to as a "test of medians", but it actually tests whether one distribution is stochastically greater than another. Here, we test whether the values of our variables (specifically, of SPREAD and VARIANCE) are generally higher in non-trading firm-years than in trading firm-years. As noted in Section 4.1, it is possible for the Mann-Whitney test to reject the equality of two distributions even when the difference between the two medians

\footnotetext{
${ }^{34}$ The p-values for SPREAD are less than 0.0001 for the tests of the mean and median differences (Mann-Whitney test); for VARIANCE the p-value is 0.0012 for the mean difference test and less than 0.0001 for the median test.
} 
Table 4

Descriptive statistics and univariate tests for sub-samples of trading and non-trading firm-year observations.

\begin{tabular}{|c|c|c|c|c|c|c|c|}
\hline Variable & Mean & Median & Standard deviation & Maximum & Minimum & Skewness & Kurtosis \\
\hline TRADING & 0.0189 & 0.0088 & 0.0288 & 0.2749 & 0.00001 & 3.8504 & 24.653 \\
\hline DUMMY TRADING & 1 & - & - & - & - & - & - \\
\hline SPREAD & $0.011^{* * *}$ & $0.01^{* * *}$ & 0.0069 & 0.0585 & 0.0007 & 2.43 & 13.9631 \\
\hline VARIANCE & $0.0005^{* * *}$ & $0.0004^{* * *}$ & 0.0004 & 0.0034 & 0.00003 & 2.5857 & 14.1542 \\
\hline VOLUME & 0.0022 & 0.0016 & 0.002 & 0.0149 & 0.0001 & 2.5398 & 12.3218 \\
\hline MARKET VALUE (€ billion) & $2.2543^{* *}$ & $0.2223^{* * *}$ & 7.1234 & 67.8091 & 0.0109 & 6.1023 & 45.5067 \\
\hline PRICE (€) & 6.6363 & $3.8614^{* * *}$ & 7.2976 & 39.5034 & 0.2532 & 2.1699 & 7.7166 \\
\hline RETURN & -0.00007 & $0.00007^{*}$ & 0.0015 & 0.0045 & -0.0055 & -0.4902 & 3.6542 \\
\hline LONG TERM VARIANCE (4 weeks) & $0.0006^{* * *}$ & $0.0003^{* *}$ & 0.0006 & 0.0048 & 0.00002 & 2.7933 & 13.0693 \\
\hline LONG TERM VARIANCE ( 6 weeks) & $0.0005^{* * *}$ & $0.0003^{* *}$ & 0.0006 & 0.0071 & 0.00001 & 4.2292 & 33 \\
\hline LONG TERM VARIANCE (8 weeks) & $0.0005^{* * *}$ & $0.0003^{* * *}$ & 0.001 & 0.0067 & 0.00001 & 3.9402 & 23.8 \\
\hline MARKET SPREAD & $0.01^{* * *}$ & $0.0054^{*}$ & 0.0081 & 0.0353 & 0.0023 & 0.9187 & 2.5266 \\
\hline MARKET VARIANCE & 0.0005 & 0.0006 & 0.0002 & 0.0009 & 0.0001 & -0.4687 & 2.2822 \\
\hline
\end{tabular}

Panel B: Sub-sample of firm-years with zero trading in own shares (943 observations)

\begin{tabular}{|c|c|c|c|c|c|c|c|}
\hline TRADING & 0 & 0 & 0 & 0 & 0 & - & - \\
\hline DUMMY TRADING & 0 & - & - & - & - & - & - \\
\hline SPREAD & 0.0181 & 0.0113 & 0.0281 & 0.6667 & 0.0006 & 13.9153 & 303.7679 \\
\hline VARIANCE & 0.0007 & 0.0005 & 0.0012 & 0.0327 & 0.00004 & 20.0406 & 514.2798 \\
\hline VOLUME & 0.0022 & 0.0016 & 0.0024 & 0.0313 & 0.00005 & 3.9748 & 33.9418 \\
\hline MARKET VALUE ( $€$ billion) & 1.5171 & 0.1897 & 5.0057 & 55.8444 & 0.0038 & 6.9309 & 60.1261 \\
\hline PRICE (€) & 6.7065 & 2.9904 & 10.9907 & 140.7835 & 0.0123 & 4.8348 & 40.2686 \\
\hline RETURN & 0.0001 & 0.0002 & 0.0018 & 0.0084 & -0.0145 & -0.8824 & 9.5396 \\
\hline LONG TERM VARIANCE (4 weeks) & 0.0007 & 0.0004 & 0.001 & 0.0106 & 0.00002 & 4.1868 & 26.7495 \\
\hline LONG TERM VARIANCE (6 weeks) & 0.0007 & 0.0004 & 0.001 & 0.01 & 0.00001 & 4.2415 & 27.5313 \\
\hline LONG TERM VARIANCE (8 weeks) & 0.0007 & 0.0004 & 0.0011 & 0.0153 & 0.00001 & 5.5139 & 49.8089 \\
\hline MARKET SPREAD & 0.0086 & 0.0054 & 0.0073 & 0.0355 & 0.0022 & 1.3519 & 3.6117 \\
\hline MARKET VARIANCE & 0.0005 & 0.0006 & 0.0002 & 0.0011 & 0.0001 & -0.3199 & 2.0963 \\
\hline
\end{tabular}

*Significant at $10 \% ;{ }^{* *}$ Significant at $5 \% ;{ }^{* *}$ Significant at $1 \%$.

Descriptive statistics and univariate tests relating to two sub-samples of a dataset of 1,365 firm-year observations for Italian companies in the period $1997-2004$. The first sub-sample comprises 422 firm-years with positive trading in own shares whereas the second sub-sample includes 943 firm-years with zero trading in own shares. Data on own-share trading are taken from companies' annual reports. Data for the other variables are obtained from Thomson Datastream. TRADING is the ratio between the number of own shares bought or sold in a given financial year and the end-of-year number of outstanding shares. DUMMY TRADING is a dummy that equals one when TRADING is positive. For each firm-year, SPREAD, VARIANCE, VOLUME, MARKET VALUE, PRICE, RETURN, and LONG TERM VARIANCE are the average daily relative bid-ask spread, daily return variance, average daily trading volume, average daily market value (in billions), average daily closing price, average daily log-return, and long-term return variance, respectively. The long-term variance is calculated using four-week, six-week, or eight-week log-returns. MARKET SPREAD and MARKET VARIANCE are the average value-weighted market daily bid-ask spread and the value-weighted market daily return variance. All variables are described in detail in Table 2. In Panel A, in the superscript of the mean of a particular variable (except TRADING and DUMMY TRADING) it is indicated whether the difference between the mean of the variable for firm-years with positive trading in own shares (422 observations) is significantly different from the mean of the same variable for firm-years with zero trading in own shares. The means of the two sub-samples are compared using a Student's $t$-tests for unpaired samples. Similarly, the results of Mann-Whitney tests evaluating whether the two sub-samples are drawn from the same population are reported in Panel A in the superscripts of the medians.

appears to be small. In Table 4, the Mann-Whitney test rejects the null hypothesis of the equality of the trading and non-trading distributions for both SPREAD and VARIANCE at significance levels of above $1 \%$. This means that the magnitude of the differences in the medians of SPREAD and VARIANCE (which seem small in absolute terms but are considerable in relative terms) seems to underestimate the magnitude of the overall differences in the distributions.

The evidence from our multivariate analyses confirms the univariate findings. Tables 5 and 6 present the multiple regressions designed to identify whether trading by companies in their own shares is a determinant of SPREAD and VARIANCE after controlling for other factors and, in the GMM models, for endogeneity of some explanatory variables. The main focus is on the coefficients on the two crucial explanatory variables: TRADING (the number of own shares traded in each firm-year divided by the number of outstanding shares at year-end) and DUMMY TRADING (coded one if TRADING is positive, and zero otherwise). If trading by companies in their own shares reduces the spread and volatility of their stocks, as predicted by Hypotheses 1 a and $2 \mathrm{a}$, we expect these coefficients to be negative and significant. Confirming these conjectures, the coefficients in the SPREAD models (Table 5) are indeed negative and statistically significant at between the $1 \%$ and $10 \%$ levels. In addition to the OLS results (reported in Columns 1 and 2 of Table 5), we also present models estimated with GMM (in Columns 3 and 4 ) that control for the fact that the decision of a company to trade its own stocks is likely to be determined by microstructure factors such as spread and volatility of the stock rendering the independent variables (DUMMY) TRADING endogenous. Two further GMM specifications are used to control for the endogeneity of the lagged dependent variable, and the results are reported in Columns (5) to (8). The GMM coefficient estimates on the trading variables are substantially larger in absolute terms (by between one to almost two orders of magnitude) than the OLS estimates. 
Table 5

Regressions for a dataset of trading in own shares comprising both firm-years with positive trading and firm-years with zero trading: dependent variable SPREAD.

\begin{tabular}{|c|c|c|c|c|c|c|c|c|}
\hline \multirow{3}{*}{$\begin{array}{l}\text { Independent } \\
\text { variables: }\end{array}$} & \multicolumn{8}{|c|}{ Dependent variable: SPREAD } \\
\hline & OLS & OLS & GMM & GMM & DIFF GMM & DIFF GMM & SYS GMM & SYS GMM \\
\hline & (1) & $(2)$ & (3) & $(4)$ & $(5)$ & $(6)$ & (7) & $(8)$ \\
\hline TRADING & $\begin{array}{l}-0.0197^{* *} \\
(-1.98)\end{array}$ & & $\begin{array}{l}-0.8668^{*} \\
(-1.71)\end{array}$ & & $\begin{array}{l}-1.4102^{* *} \\
(-2.19)\end{array}$ & & $\begin{array}{l}-1.179^{* *} \\
(-2.04)\end{array}$ & \\
\hline DUMMY TRADING & & $\begin{array}{l}-0.0012^{* *} \\
(-2.18)\end{array}$ & & $\begin{array}{l}-0.0123^{*} \\
(-1.75)\end{array}$ & & $\begin{array}{l}-0.0504^{* *} \\
(-2.59)\end{array}$ & & $\begin{array}{l}-0.0387^{* * *} \\
(-2.87)\end{array}$ \\
\hline SPREAD $(t-1)$ & $\begin{array}{l}0.6702^{\text {**** }} \\
(10.44)\end{array}$ & $\begin{array}{l}0.665^{* * *} \\
(10.24)\end{array}$ & $\begin{array}{l}0.6686^{* * *} \\
(10.41)\end{array}$ & $\begin{array}{l}0.5974^{* * *} \\
(8.95)\end{array}$ & $\begin{array}{l}0.2582^{* * *} \\
(3.65)\end{array}$ & $\begin{array}{l}0.2758^{* * *} \\
(4.12)\end{array}$ & $\begin{array}{l}0.3969^{* * *} \\
(3.33)\end{array}$ & $\begin{array}{l}0.342^{* * *} \\
(4.27)\end{array}$ \\
\hline VARIANCE & $\begin{array}{l}6.492^{* *} \\
(2.3)\end{array}$ & $\begin{array}{l}6.482^{* * *} \\
(2.31)\end{array}$ & $\begin{array}{l}-0.7123 \\
(-0.18)\end{array}$ & $\begin{array}{l}4.128 \\
(1.51)\end{array}$ & $\begin{array}{l}0.191 \\
(0.07)\end{array}$ & $\begin{array}{l}0.4691 \\
(0.16)\end{array}$ & $\begin{array}{l}-0.9013 \\
(-0.23)\end{array}$ & $\begin{array}{l}1.0293 \\
(0.4)\end{array}$ \\
\hline VOLUME & $\begin{array}{l}-0.7562^{* * *} \\
(-2.66)\end{array}$ & $\begin{array}{l}-0.7548^{* * *} \\
(-2.7)\end{array}$ & $\begin{array}{l}0.0613 \\
(0.16)\end{array}$ & $\begin{array}{l}-0.4686^{* *} \\
(-2.02)\end{array}$ & $\begin{array}{l}0.3835 \\
(0.68)\end{array}$ & $\begin{array}{l}0.514 \\
(0.84)\end{array}$ & $\begin{array}{l}-0.7204 \\
(-0.81)\end{array}$ & $\begin{array}{l}-0.224 \\
(-0.45)\end{array}$ \\
\hline MARKET VALUE & $\begin{array}{l}-0.00003 \\
(-0.54)\end{array}$ & $\begin{array}{l}-0.00002 \\
(-0.35)\end{array}$ & $\begin{array}{l}-0.0002^{* *} \\
(-2.04)\end{array}$ & $\begin{array}{l}0.00003 \\
(0.4)\end{array}$ & $\begin{array}{l}0.0002 \\
(0.64)\end{array}$ & $\begin{array}{l}0.0012 \\
(1.63)\end{array}$ & $\begin{array}{l}-0.0004^{*} \\
(-1.84)\end{array}$ & $\begin{array}{l}0.0000002 \\
(0.5)\end{array}$ \\
\hline PRICE & $\begin{array}{l}-0.00004 \\
(-1.24)\end{array}$ & $\begin{array}{l}-0.00004 \\
(-1.25)\end{array}$ & $\begin{array}{l}-0.00004 \\
(-0.53)\end{array}$ & $\begin{array}{l}-0.00004 \\
(-0.91)\end{array}$ & $\begin{array}{l}-0.0002 \\
(-0.79)\end{array}$ & $\begin{array}{l}-0.0004 \\
(-1)\end{array}$ & $\begin{array}{l}-0.00007 \\
(-0.45)\end{array}$ & $\begin{array}{l}-0.0001 \\
(-1.24)\end{array}$ \\
\hline MARKET SPREAD & $\begin{array}{l}0.0575 \\
(0.28)\end{array}$ & $\begin{array}{l}0.071 \\
(0.36)\end{array}$ & $\begin{array}{l}0.0606 \\
(0.32)\end{array}$ & $\begin{array}{l}0.1945 \\
(1.08)\end{array}$ & $\begin{array}{l}-0.0644 \\
(-0.49)\end{array}$ & $\begin{array}{l}0.0913 \\
(0.36)\end{array}$ & $\begin{array}{l}0.0336 \\
(0.23)\end{array}$ & $\begin{array}{l}0.1952 \\
(0.93)\end{array}$ \\
\hline Constant & $\begin{array}{l}0.0022 \\
(0.5)\end{array}$ & $\begin{array}{l}0.0023 \\
(0.51)\end{array}$ & $\begin{array}{l}0.0076 \\
(1.35)\end{array}$ & $\begin{array}{l}0.0046 \\
(0.94)\end{array}$ & - & - & $\begin{array}{l}0.014^{* * * *} \\
(3.77)\end{array}$ & $\begin{array}{l}0.0171^{* * *} \\
(4.13)\end{array}$ \\
\hline$p$-value $\mathrm{AR}(1)$ test & - & - & - & - & 0.077 & 0.018 & 0.05 & 0.015 \\
\hline$p$-value $\operatorname{AR}(2)$ test & - & - & - & - & 0.157 & 0.17 & 0.299 & 0.229 \\
\hline$p$-value Sargan test & - & - & - & - & 0.066 & 0.364 & 0.362 & 0.136 \\
\hline p-value Hansen test & - & - & 0.1396 & 0.056 & 0.294 & 0.758 & 0.103 & 0.676 \\
\hline Adjusted R squared & 0.7063 & 0.7068 & - & - & - & - & - & - \\
\hline Observations & 788 & 788 & 788 & 788 & 788 & 788 & 788 & 788 \\
\hline
\end{tabular}

*Significant at $10 \%$; ${ }^{* *}$ Significant at $5 \%$; $* * *$ Significant at $1 \%$.

Regressions for a dataset of 788 firm-year observations for Italian companies in the period 1997-2004. Data on trading in own shares are obtained from companies' annual reports. Data for the other variables used in the regressions come from Thomson Datastream and Worldscope. The dependent variable SPREAD is the average daily bid-ask spread in a fiscal year. SPREAD $(t-1)$ is the lagged value of the dependent variable. TRADING is the ratio between the number of own shares traded in a year and the end-of-year number of outstanding shares. DUMMY TRADING is a dummy that equals one when TRADING is positive. For each firm-year, VARIANCE, VOLUME, MARKET VALUE, PRICE, and MARKET SPREAD are the daily return variance, average daily trading volume, average daily market value (in billions), average daily closing price, and average value-weighted market daily bid-ask spread, respectively. All variables are described in detail in Table 2. Ordinary least squares (OLS) estimations are reported in the first two columns. In Columns (3) to (8), the variables for trading in own shares (TRADING and DUMMY TRADING) are treated as endogenous. The models in Columns (3) and (4) are estimated adopting a generalized method of moments approach (GMM) and using as instruments for the two own-shares trading variables the lagged values of both operating and non-operating income scaled by total assets at the end of the previous year (Stata command ivreg2). The models of Columns (5) and (6) are estimated adopting the difference GMM method of Arellano and Bond for dynamic panel data models (Stata command xtabond2). The first difference of the variable SPREAD $(t-1)$ is instrumented by the variable SPREAD ( $t-2$ ) and the first differences for the trading in own shares variables are instrumented by the first differences of both the lagged values of operating and non-operating income scaled by total assets. The models of Columns (7) and (8) are estimated through an Arellano-Bover/Blundell-Bond system GMM estimator for dynamic panel data models (Stata command xtabond2). The system GMM extends the difference GMM in that, besides the model in differences, an equation in levels is also estimated. In the levels equation, the first difference of SPREAD $(t-1)$ is used as an instrument for $\operatorname{SPREAD}(t-1)$. The two trading in own shares variables are instrumented by lagged values of both operating and non-operating income scaled by total assets. Two-sided $p$-values of the Arellano and Bond tests of the presence of first- (AR (1)) and second-order $(A R(2))$ serial correlation in the residuals are reported. The table also reports the two-sided $p$-values of the Sargan and Hansen tests, for which the null hypothesis is the joint validity of all the instruments (all moment conditions). Two sets of dummy variables, one with seven year dummies and one with six industry dummies, are always included among the independent variables. Results for these dummies are not reported. Robust $t$-statistics for heteroskedasticity and serial correlation, within each cross-section, are reported in parentheses.

The GMM estimates on the TRADING coefficient in the SPREAD model range from -0.87 to -1.41 . This means a one-standard deviation change in TRADING reduces SPREAD by between 1.054 and 1.715 standard deviations. ${ }^{35}$ Based on the OLS results, the relative impact is much lower at only 0.024 standard deviations. However, as we argued above, we believe the OLS estimates to be biased and inconsistent.

Similarly, in the VARIANCE models in Table 6, the estimated coefficients on the continuous and binary trading variable are of the expected negative sign and significant in all cases except the GMM regressions using the continuous TRADING variable (reported in Columns 3 to 8$).{ }^{36}$ As in the SPREAD models, the use of GMM results in substantially larger coefficient estimates (in absolute terms).

\footnotetext{
35 This is calculated by multiplying the coefficient estimate on TRADING by the standard deviation of TRADING $(\mathrm{SD}=0.0197)$ and then dividing by the standard deviation of SPREAD $(S D=0.0162)$. The standard deviations are calculated for the subsample of 788 observations used in the regression analysis, as shown in Panel B of Table 3.

${ }^{36}$ In Table 6, LONG TERM VARIANCE is calculated using returns over six-week intervals. Findings are qualitatively similar if four- and eight-week intervals are used instead.
} 
Table 6

Regressions for a dataset of trading in own shares comprising both firm-years with positive trading and firm-years with zero trading: dependent variable VARIANCE.

\begin{tabular}{|c|c|c|c|c|c|c|c|c|}
\hline \multirow{3}{*}{$\begin{array}{l}\text { Independent } \\
\text { variables: }\end{array}$} & \multicolumn{8}{|c|}{ Dependent variable: VARIANCE } \\
\hline & OLS & OLS & GMM & GMM & DIFF GMM & DIFF GMM & SYS GMM & SYS GMM \\
\hline & $(1)$ & $(2)$ & (3) & $(4)$ & (5) & $(6)$ & (7) & $(8)$ \\
\hline TRADING & $\begin{array}{l}-0.001^{* * *} \\
(-3.3)\end{array}$ & & $\begin{array}{l}-0.0402 \\
(-1.26)\end{array}$ & & $\begin{array}{l}-0.0338 \\
(-1.25)\end{array}$ & & $\begin{array}{l}-0.0074 \\
(-1.01)\end{array}$ & \\
\hline DUMMY TRADING & & $\begin{array}{l}-0.00004^{* * *} \\
(-2.78)\end{array}$ & & $\begin{array}{l}-0.0006^{*} \\
(-1.79)\end{array}$ & & $\begin{array}{l}-0.0023^{* *} \\
(-2.55)\end{array}$ & & $\begin{array}{l}-0.0008^{* * *} \\
(-2.24)\end{array}$ \\
\hline VARIANCE $(t-1)$ & $\begin{array}{l}0.1863^{* * * *} \\
(5.06)\end{array}$ & $\begin{array}{l}0.1858^{* * * *} \\
(5.03)\end{array}$ & $\begin{array}{l}-0.0266 \\
(-0.16)\end{array}$ & $\begin{array}{l}0.1025^{*} \\
(1.68)\end{array}$ & $\begin{array}{l}0.0018^{* * *} \\
(2.11)\end{array}$ & $\begin{array}{l}0.0021^{* *} \\
(2.04)\end{array}$ & $\begin{array}{l}0.0015^{*} \\
(1.82)\end{array}$ & $\begin{array}{l}0.0014 \\
(1.45)\end{array}$ \\
\hline SPREAD & $\begin{array}{l}0.0078^{* * *} \\
(5.92)\end{array}$ & $\begin{array}{l}0.0076^{* * *} \\
(5.71)\end{array}$ & $\begin{array}{l}0.0047 \\
(1.63)\end{array}$ & $\begin{array}{l}0.0044^{*} \\
(1.72)\end{array}$ & $\begin{array}{l}0.0029 \\
(1.03)\end{array}$ & $\begin{array}{l}0.0021 \\
(0.75)\end{array}$ & $\begin{array}{l}0.0062^{* * *} \\
(2.92)\end{array}$ & $\begin{array}{l}0.0032 \\
(1.25)\end{array}$ \\
\hline VOLUME & $\begin{array}{l}0.0363^{* * *} \\
(2.98)\end{array}$ & $\begin{array}{l}0.0365^{* * * *} \\
(2.96)\end{array}$ & $\begin{array}{l}0.0502^{* * *} \\
(2.61)\end{array}$ & $\begin{array}{l}0.0436^{* * *} \\
(2.76)\end{array}$ & $\begin{array}{l}0.0885^{* * *} \\
(3.91)\end{array}$ & $\begin{array}{l}0.0911^{* * *} \\
(2.95)\end{array}$ & $\begin{array}{l}0.0685^{* * *} \\
(3.12)\end{array}$ & $\begin{array}{l}0.0611^{* *} \\
(2.53)\end{array}$ \\
\hline RETURN & $\begin{array}{l}-0.0089 \\
(-0.72)\end{array}$ & $\begin{array}{l}-0.0092 \\
(-0.75)\end{array}$ & $\begin{array}{l}0.0085 \\
(0.38)\end{array}$ & $\begin{array}{l}-0.0074 \\
(-0.55)\end{array}$ & $\begin{array}{l}-0.0152 \\
(-0.63)\end{array}$ & $\begin{array}{l}-0.001 \\
(-0.04)\end{array}$ & $\begin{array}{l}-0.0076 \\
(-0.54)\end{array}$ & $\begin{array}{l}-0.0069 \\
(-0.49)\end{array}$ \\
\hline LONG TERM VARIANCE & $\begin{array}{l}0.3081^{* * * *} \\
(6.22)\end{array}$ & $\begin{array}{l}0.3091^{* * * *} \\
(6.23)\end{array}$ & $\begin{array}{l}0.2728^{* * *} \\
(4.81)\end{array}$ & $\begin{array}{l}0.312^{* * *} \\
(6.7)\end{array}$ & $\begin{array}{l}0.2313^{* * *} \\
(3.35)\end{array}$ & $\begin{array}{l}0.254^{* * * *} \\
(4.52)\end{array}$ & $\begin{array}{l}0.3333^{* * * *} \\
(4.45)\end{array}$ & $\begin{array}{l}0.3164^{* * * *} \\
(4.39)\end{array}$ \\
\hline MARKET VARIANCE & $\begin{array}{l}0.3145 \\
(1.54)\end{array}$ & $\begin{array}{l}0.3117 \\
(1.52)\end{array}$ & $\begin{array}{l}0.771 \\
(1.31)\end{array}$ & $\begin{array}{l}0.4361 \\
(1.3)\end{array}$ & $\begin{array}{l}-0.6009 \\
(-0.74)\end{array}$ & $\begin{array}{l}-0.4422 \\
(-0.8)\end{array}$ & $\begin{array}{l}-0.0586 \\
(-0.18)\end{array}$ & $\begin{array}{l}0.079 \\
(0.24)\end{array}$ \\
\hline Constant & $\begin{array}{l}-0.0001 \\
(-0.78)\end{array}$ & $\begin{array}{l}-0.0001 \\
(-0.75)\end{array}$ & $\begin{array}{l}-0.0003 \\
(-0.75)\end{array}$ & $\begin{array}{l}-0.0001 \\
(-0.48)\end{array}$ & - & - & $\begin{array}{l}0.0001 \\
(0.76)\end{array}$ & $\begin{array}{l}0.0003 \\
(1.38)\end{array}$ \\
\hline$p$-value $\mathrm{AR}(1)$ test & - & - & - & - & 0.116 & 0.017 & $<0.0001$ & $<0.0001$ \\
\hline$p$-value $\mathrm{AR}(2)$ test & - & - & - & - & 0.155 & 0.175 & 0.019 & 0.156 \\
\hline$p$-value Sargan test & - & - & - & - & 0.289 & 0.337 & $<0.0001$ & $<0.0001$ \\
\hline$p$-value Hansen test & - & - & 0.975 & 0.9105 & 0.173 & 0.463 & 0.045 & 0.182 \\
\hline Adjusted R squared & 0.6973 & 0.6971 & - & - & - & - & - & - \\
\hline Observations & 788 & 788 & 788 & 788 & 788 & 788 & 788 & 788 \\
\hline
\end{tabular}

*Significant at $10 \% ;{ }^{* *}$ Significant at $5 \% ;{ }^{* * *}$ Significant at $1 \%$.

Regressions for a dataset of 788 firm-year observations for Italian companies in the period 1997-2004. Trading in own-shares data are obtained from companies' annual reports. Data for the other variables used in the regressions is obtained from Thomson Datastream and Worldscope. The dependent variable VARIANCE is the daily return variance in a fiscal year. VARIANCE $(t-1)$ is the lagged value of the dependent variable. TRADING is the ratio between the number of own-shares traded in a year and the end-of-year number of outstanding shares. DUMMY TRADING is a dummy that equals one when TRADING is positive. For each firm-year, SPREAD, VOLUME, RETURN, LONG TERM VARIANCE, and MARKET VARIANCE are the average daily bid-ask spread, the average daily trading volume, the average daily log-return, the long term variance (computed using six-weekly log-returns), and the value-weighted market daily return variance, respectively. All variables are described in detail in Table 2. Ordinary least squares (OLS) estimations are reported in the first two columns. In Columns (3) to (8), the variables for trading in own shares (TRADING and DUMMY TRADING) are assumed endogenous. The models in columns (3) and (4) are estimated adopting a generalised method of moments approach (GMM) and using as instruments for the two trading in own-shares variables the lagged values of both operating and non-operating income scaled by total assets at the end of the previous year (Stata command ivreg2). The models of columns (5) and (6) are estimated adopting the difference GMM method of Arellano and Bond for dynamic panel data models (Stata command $x$ tabond2). The first difference of the variable VARIANCE $(t-1)$ is instrumented by the variable VARIANCE $(t-2)$ and the first differences for the trading in own-shares variables are instrumented by the first differences of both the lagged values of operating and non-operating income scaled by total assets. The model of Columns (7) and (8) is estimated through an Arellano-Bover/Blundell-Bond system GMM estimator for dynamic panel data models (Stata command xtabond2). The system GMM extends the difference GMM in that, besides the model in differences, an equation in levels is also estimated. In the levels equation, the first difference of VARIANCE $(t-1)$ is used as an instrument for VARIANCE ( $t-1)$. The two trading in own-shares variables are instrumented by lagged values of both operating and non-operating income scaled by total assets. Two-sided $p$-values of the Arellano and Bond tests of the presence of first- $(A R(1))$ and second-order $(A R(2))$ serial correlation in the residuals are reported. The table also reports the two-sided $p$ values of the Sargan and Hansen tests, for which the null hypothesis is the jointly validity of all the instruments (all moment conditions). Two sets of dummy variables, one with seven year dummies and one with six industry dummies, are always included among the independent variables. Results for these dummies are not reported. Robust t-statistics for heteroskedasticity and serial correlation, within each cross-section, are reported in parentheses.

The coefficients on the control variables normally have the expected signs even though they are sometimes weakly or not statistically significant. The lagged dependent variables are almost always significant. In Table 5, the coefficient on lagged SPREAD is quite high, ranging from 0.26 to 0.67 , indicating considerable persistence in the variable. In Table 6 by contrast, the lagged VARIANCE coefficients are close to zero and not always significant, owing to the presence of other independent variables.

In Columns (5) to (8) of Tables 5 and 6, in most cases the $p$-values of the Sargan/Hansen tests (Bond, 2002; Roodman, 2006) indicate that the instruments used are jointly exogenous. In unreported tests, we also verify whether the variables TRADING and DUMMY TRADING are endogenous in the models of Columns (5) to (8) of Tables 5 and 6 through difference-in-Sargan tests (Baum et al., 2003). We find that these variables are always endogenous except in the regressions of Columns (3) and (4) of Table 5.

In conclusion, our findings provide evidence that the trading by companies of their own shares is associated with lower levels of spread and volatility of the companies' stocks, as predicted by Hypotheses 1a and 2a.

\subsection{Effects of repurchase approvals on spread and volatility}

Table 7 presents descriptive statistics relating to the second approach examining the impact of repurchase approvals at AGMs on spread and volatility. The means of SPREAD CHANGE and VARIANCE CHANGE are negative and statistically significantly different 
Table 7

Descriptive statistics for a dataset of annual general meetings (AGMs) comprising both repurchase approval and non-approval AGMs.

\begin{tabular}{|c|c|c|c|c|c|c|c|c|}
\hline \multicolumn{9}{|l|}{ Panel A: Overall sample of observations } \\
\hline Variable & Observations & Mean & Median & Standard deviation & Maximum & Minimum & Skewness & Kurtosis \\
\hline APPROVAL AGM & 1356 & 0.3429 & - & - & - & - & - & - \\
\hline SPREAD CHANGE & 1356 & $-0.0893^{* * *}$ & $-0.0677^{* * *}$ & 0.5147 & 2.4196 & -3.9583 & -1.8013 & 10.695 \\
\hline VARIANCE CHANGE & 1356 & $-0.167^{* * *}$ & $-0.1327^{* * *}$ & 0.7892 & 3.7945 & -3.3977 & -0.0026 & 0.9791 \\
\hline IPO & 1356 & 0.0944 & - & - & - & - & - & - \\
\hline VOLUME CHANGE & 1356 & $-0.2299^{* * *}$ & $-0.2021^{* * *}$ & 0.7773 & 3.3452 & -3.7451 & 0.012 & 1.1996 \\
\hline PRICE CHANGE & 1356 & $-0.0224^{* * *}$ & -0.0034 & 0.2461 & 1.134 & -1.5157 & -0.6775 & 3.3902 \\
\hline LONG TERM VARIANCE CHANGE (2 weeks) & 1356 & $-0.156^{* * *}$ & $-0.1852^{* * *}$ & 1.2401 & 3.9513 & -4.3943 & 0.0493 & -0.0603 \\
\hline LONG TERM VARIANCE CHANGE (3 weeks) & 1356 & $-0.1639^{* * *}$ & $-0.221^{* * *}$ & 1.3684 & 5.7658 & -4.5392 & 0.0805 & 0.3334 \\
\hline LONG TERM VARIANCE CHANGE (4 weeks) & 1356 & $-0.1411^{* * *}$ & $-0.165^{* * *}$ & 1.5247 & 5.0067 & -7.5447 & -0.1078 & 0.5918 \\
\hline MARKET SPREAD CHANGE & 1356 & $-0.4292^{* * *}$ & $-0.1783^{* * *}$ & 0.7865 & 2.7184 & -2.6541 & -1.1364 & 1.9145 \\
\hline MARKET VARIANCE CHANGE & 1356 & $-0.2537^{* * *}$ & $-0.4165^{* * *}$ & 0.6573 & 1.3235 & -1.3434 & 0.0691 & -1.4184 \\
\hline \multicolumn{9}{|c|}{ Panel B: Samples of approval and non-approval AGMs } \\
\hline Variable & Observations & Mean & Median & Standard deviation & Maximum & Minimum & Skewness & Kurtosis \\
\hline \multicolumn{9}{|l|}{ SPREAD CHANGE } \\
\hline Approval AGMs & 465 & $-0.1483^{* * *}$ & $-0.1203^{* * *}$ & 0.5364 & 1.291 & -3.9583 & -2.5844 & 13.4875 \\
\hline Non-approval AGMs & 891 & $-0.0586^{* * *}$ & $-0.0513^{* * *}$ & 0.5006 & 2.4196 & -3.2185 & -1.3014 & 8.5504 \\
\hline \multicolumn{9}{|l|}{ VARIANCE CHANGE } \\
\hline Approval AGMs & 465 & $-0.2099^{* * *}$ & $-0.2234^{* * *}$ & 0.728 & 2.3521 & -2.0433 & 0.1493 & -0.0719 \\
\hline Non-approval AGMs & 891 & $-0.1446^{* * *}$ & $-0.1006^{* * *}$ & 0.8189 & 3.7945 & -3.3977 & -0.0754 & 1.2921 \\
\hline
\end{tabular}

*Significant at $10 \%$; **Significant at $5 \%$; ${ }^{* * *}$ Significant at $1 \%$.

Descriptive statistics related to the variables used in the empirical analyses of a dataset of 1,356 annual general meeting (AGM) dates of Italian companies in the period 1997-2004. In this sample, there are 465 repurchase AGMs that approved a repurchase program and 891 non-repurchase AGMs. Data for the AGM dates are obtained from Factiva and from companies' annual reports. Data for the other variables are obtained from Thomson Datastream and from the website of the Italian stock exchange (www.borsaitaliana.it). APPROVAL AGM is a dummy that equals one for repurchase AGMs. SPREAD CHANGE, VARIANCE CHANGE, VOLUME CHANGE, PRICE CHANGE, and LONG TERM VARIANCE CHANGE are the logarithm of one plus the relative changes, around the AGMs, in daily bid-ask spread, daily return variance, daily trading volume, daily closing price, and long-term return variance, respectively. The long-term variance is calculated using two-week, three-week, or four-week log-returns. MARKET SPREAD CHANGE and MARKET VARIANCE CHANGE are the logarithm of one plus the relative changes, around AGMs, in the valueweighted market daily bid-ask spread and daily return variance. IPO is a dummy that equals one if part of the first year of trading (253 trading days) of the stock is comprised in the interval of calculation of relative changes. All variables are described in detail in Table 2. For non-binary variables, the results of a two-sided Student's $t$-test on the significance of mean values and of a two-sided Wilcoxon signed rank test on the significance of median values are reported.

from zero irrespective of whether the AGM approved a repurchase program or not (see Panels A and B of Table 7). This may reflect long-term trends in the quality of the Italian stock market. Alternatively (or in addition), this may be due to seasonal patterns as AGMs in Italy are typically clustered between April and June.

We test whether the mean and median values of SPREAD CHANGE and VARIANCE CHANGE around the AGM differ statistically between repurchase approval and non-approval AGMs. In Panel A of Table 8, we report standard $t$-statistics to test for the equality of means and Mann-Whitney tests for medians. Consistent with Hypothesis 1a, there is a statistically significantly greater reduction in relative spreads around approval than around non-approval AGMs. The result is highly significant with $p$-values around $0.2 \%$ in both the $t$-test on means and the non-parametric Mann-Whitney test on medians.

To test Hypotheses $2 \mathrm{a}$ and $2 \mathrm{~b}$, we examine whether the approval of a repurchase program at an AGM reduces the short-term variance of the stock more than for comparable non-approval AGMs. As the results in Panel A of Table 8 show, we find evidence of a more pronounced reduction in variance around approval AGMs, consistent with Hypothesis 2a. The difference in VARIANCE CHANGE between approval and non-approval AGMs is statistically significant at the $6 \%$ level (in the Mann-Whitney test of medians). In the standard $t$-test the difference is only significant at the $15 \%$ level, considerably below conventional levels of significance.

Next, we examine whether the difference in SPREAD and VARIANCE CHANGE depends on the pre-AGM level, and whether the results above are driven by observations with high or low pre-AGM levels. In the spirit of Hypotheses 1a and 2a, we might expect to find the beneficial impact of repurchase approvals on spread and variance to be particularly apparent for stocks that were exceptionally illiquid and volatile prior to the approval announcement. We rank the repurchase AGMs by the levels of spread and volatility in the pre-AGM period (days $-120,-11$ ), and group them into terciles each comprising 155 observations. The control sample is created by matching each of the 155 observations in each of the repurchase terciles with a corresponding nonrepurchase AGM by fiscal year and by the pre-AGM level of spread and volatility. As Panel B of Table 8 shows, the difference between repurchasing and non-repurchasing AGMs is indeed most pronounced and only significant for the tercile with the highest pre-AGM levels of spread and volatility.

To summarize, consistent with Hypotheses 1a and 2a, repurchase approvals are associated with abnormal decreases in spread and volatility, and these decreases are particularly pronounced among illiquid and highly volatile stocks.

We further examine these findings using multivariate analysis. We regress SPREAD CHANGE and VARIANCE CHANGE on a dummy variable indicating whether the AGM approved a repurchase program (APPROVAL AGM) and several control variables as 
Table 8

Univariate tests for a dataset of annual general meetings (AGMs) comprising both repurchase approval and non-approval AGMs.

\begin{tabular}{|c|c|c|c|c|c|c|}
\hline Variable & $\begin{array}{l}\text { Approval AGMs } \\
\text { (mean) }\end{array}$ & $\begin{array}{l}\text { Non-approval } \\
\text { AGMs (mean) }\end{array}$ & $\begin{array}{l}\text { Approval AGMs } \\
\text { (median) }\end{array}$ & $\begin{array}{l}\text { Non-approval AGMs } \\
\text { (median) }\end{array}$ & $\begin{array}{l}\text { Student's } t \text {-test } \\
\text { (two-sided } p \text {-value) }\end{array}$ & $\begin{array}{l}\text { Mann-Whitney } \\
\text { test (two-sided } p \text {-value) }\end{array}$ \\
\hline SPREAD CHANGE & -0.1483 & -0.0586 & -0.1203 & -0.0513 & 0.0023 & 0.0017 \\
\hline VARIANCE & -0.2099 & -0.1446 & -0.2234 & -0.1006 & 0.1484 & 0.0624 \\
\hline
\end{tabular}

CHANGE

Panel B: Sub-samples of approval AGMs (155 observations) vs. sub-samples of 155 matched non-approval AGMs

\begin{tabular}{|c|c|c|c|c|c|c|}
\hline \multicolumn{7}{|l|}{ SPREAD CHANGE } \\
\hline Low pre-AGM spread & -0.0663 & -0.0135 & -0.1076 & -0.0631 & 0.1867 & 0.3791 \\
\hline Medium pre-AGM spread & -0.0493 & -0.0552 & -0.0602 & -0.0379 & 0.8894 & 0.8741 \\
\hline High pre-AGM spread & -0.3293 & -0.1995 & -0.1603 & -0.1449 & 0.0896 & 0.3432 \\
\hline \multicolumn{7}{|l|}{ VARIANCE CHANGE } \\
\hline Low pre-AGM variance & 0.0654 & 0.1142 & -0.0006 & 0.0223 & 0.5332 & 0.5296 \\
\hline $\begin{array}{l}\text { Medium pre-AGM } \\
\text { variance }\end{array}$ & -0.1373 & -0.1597 & -0.121 & 0.0046 & 0.7855 & 0.9646 \\
\hline High pre-AGM variance & -0.5577 & -0.356 & -0.6528 & -0.2779 & 0.0108 & 0.0119 \\
\hline
\end{tabular}

Univariate tests on the differences between mean and median values of the variables SPREAD CHANGE and VARIANCE CHANGE for annual general meetings (AGMs) that approved a repurchase program (repurchase AGMs) and mean and median values of the same variables for AGMs that did not approve a repurchase program (non-repurchase AGMs). Data for the AGM dates, which are made up of Italian AGMs in the period 1997-2004, are obtained from Factiva and from companies' annual reports. Data for the variables SPREAD CHANGE and VARIANCE CHANGE are obtained from Thomson Datastream. SPREAD CHANGE and VARIANCE CHANGE are the logarithm of one plus the relative changes, around AGMs, in daily bid-ask spread and daily return variance. These variables are described in detail in Table 2 . In Panel A, the mean value of either SPREAD CHANGE or VARIANCE CHANGE for approval AGMs (465 observations) is formally compared with the mean value for nonapproval AGMs (891 observations) through a Student's t-test for unpaired samples. We also report Mann-Whitney tests comparing the medians of SPREAD CHANGE and VARIANCE CHANGE for approval AGMs with the medians for non-approval AGMs. In Panel B, for each variable the sample of repurchase AGMs is divided into three sub-samples of equal size, with low, medium, and high values of either bid-ask spread (for SPREAD CHANGE) or return variance (for VARIANCE CHANGE) in the pre-AGM period (from trading days -120 to -11 , with trading day 0 being the AGM date). The mean of each sub-sample of approval AGMs is formally compared with the mean of a matching sample of non-repurchase AGMs through a Student's t-test for unpaired samples. Mann-Whitney tests are used in a similar way to test whether sub-samples of approval AGMs and corresponding sub-samples of non-approval AGMs are drawn from the same populations. The matching samples are constructed by finding for each approval AGM a matching non-approval AGM having the most similar pre-AGM value of either bid-ask spread (for SPREAD CHANGE) or return variance (for VARIANCE CHANGE) and occurring in the same fiscal year.

outlined in the previous section. The results are presented in Table 9. As predicted by Hypothesis 1a, the coefficient on APPROVAL AGM is negative $(-0.0507)$ and statistically significant at just over the $10 \%$ level, indicating that repurchase approvals reduce spreads. The coefficient on APPROVAL AGM in the VARIANCE CHANGE regression is also negative but clearly insignificant. Thus, the significance of the impact of repurchase approvals on variance documented in our univariate analyses appears to disappear in the multivariate analysis.

The coefficients on the control variables VOLUME CHANGE and PRICE CHANGE have the expected signs but only VOLUME CHANGE is highly statistically significant in all regressions. In the SPREAD CHANGE regression, the variables VARIANCE CHANGE and MARKET SPREAD CHANGE are also highly significant. Similarly, in the VARIANCE CHANGE models, SPREAD CHANGE and MARKET VARIANCE CHANGE are highly statistically significant with the expected signs. Also, the change in fundamental variance (LONG TERM VARIANCE CHANGE), based variously on returns over intervals of two, three, and four weeks, is highly statistically significant with the expected positive sign. The change in stock prices has a negative and (marginally) significant impact on VARIANCE CHANGE, but no effect on SPREAD CHANGE. Recent listings appear to behave no differently than seasoned stocks as indicated by the insignificance of the IPO dummy coefficient.

As in the univariate analysis, we split the sample into terciles of 155 observations and estimate a separate regression for each tercile and their 155 matched control AGMs (310 observations in total). This allows us to investigate whether the findings in the earlier regression models are dependent on pre-AGM levels of spread and volatility. Table 10 reports the estimated coefficients on APPROVAL AGM for each of the three sub-samples of 310 observations corresponding to low, medium, and high pre-AGM levels. The coefficient in the SPREAD CHANGE models is negative for observations with low and high pre-AGM spread but positive for those with medium spread. It is statistically significant only for stocks with high pre-AGM spread. In line with our univariate results, our findings of a significant effect of repurchase approvals on spread changes appear to be primarily driven by illiquid stocks.

In the corresponding regressions for VARIANCE CHANGE the coefficient on APPROVAL AGM is negative with only one exception. However, this coefficient is almost never statistically significant-the single exception is in the regression using the three-week version of LONG TERM VARIANCE on the sub-sample with lowest pre-AGM volatility. The finding of weak statistical significance is similar to the univariate results, but oddly in the univariate analysis the volatility-reduction result was driven by the most volatile stocks, while the multivariate analysis finds significant results only for the least volatile stocks.

To summarize, our multivariate analysis confirms that, as predicted by Hypothesis 1a, repurchases are associated with a significant decrease in spreads and this result is driven by illiquid stocks. Our analysis of volatility also finds some evidence of an 
Table 9

Regressions for a dataset of annual general meetings (AGMs) comprising both approval and non-approval AGMs.

\begin{tabular}{|c|c|c|c|c|}
\hline & \multicolumn{4}{|c|}{ Dependent variable: } \\
\hline & SPREAD CHANGE & VARIANCE CHANGE & VARIANCE CHANGE & VARIANCE CHANGE \\
\hline & $(1)$ & $(2)$ & (3) & $(4)$ \\
\hline \multicolumn{5}{|l|}{ Independent variables } \\
\hline APPROVAL AGM & $\begin{array}{l}-0.0507^{*} \\
(-1.79)\end{array}$ & $\begin{array}{l}-0.0165 \\
(-0.64)\end{array}$ & $\begin{array}{l}-0.011 \\
(-0.43)\end{array}$ & $\begin{array}{l}-0.0208 \\
(-0.76)\end{array}$ \\
\hline SPREAD CHANGE & & $\begin{array}{l}0.116^{* * *} \\
(3.37)\end{array}$ & $\begin{array}{l}0.1464^{* * *} \\
(3.99)\end{array}$ & $\begin{array}{l}0.149^{* * *} \\
(3.44)\end{array}$ \\
\hline VARIANCE CHANGE & $\begin{array}{l}0.1265^{* * *} \\
(5.02)\end{array}$ & & & \\
\hline IPO & $\begin{array}{l}0.0436 \\
(1.46)\end{array}$ & $\begin{array}{l}-0.029 \\
(-0.72)\end{array}$ & $\begin{array}{l}-0.0064 \\
(-0.15)\end{array}$ & $\begin{array}{l}-0.0358 \\
(-0.16)\end{array}$ \\
\hline VOLUME CHANGE & $\begin{array}{l}-0.1823^{* * *} \\
(-7.27)\end{array}$ & $\begin{array}{l}0.1854^{* * *} \\
(6.76)\end{array}$ & $\begin{array}{l}0.2763^{* * *} \\
(10.07)\end{array}$ & $\begin{array}{l}0.2985^{* * *} \\
(9.57)\end{array}$ \\
\hline PRICE CHANGE & $\begin{array}{l}-0.028 \\
(-0.39)\end{array}$ & $\begin{array}{l}-0.1314^{*} \\
(-1.78)\end{array}$ & $\begin{array}{l}-0.1481^{* *} \\
(-1.99)\end{array}$ & $\begin{array}{l}-0.1222 \\
(-1.53)\end{array}$ \\
\hline $\begin{array}{l}\text { LONG TERM VARIANCE } \\
\text { CHANGE ( } 2 \text { weeks) }\end{array}$ & & $\begin{array}{l}0.3532^{* * *} \\
(18.44)\end{array}$ & & \\
\hline LONG TERM VARIANCE & & & $0.255^{* * *}$ & \\
\hline CHANGE (3 weeks) & & & $(15.97)$ & \\
\hline LONG TERM VARIANCE & & & & $0.1856^{* * * *}$ \\
\hline CHANGE (4 weeks) & & & & $(12.16)$ \\
\hline MARKET SPREAD CHANGE & $\begin{array}{l}0.1661^{* * *} \\
(2.66)\end{array}$ & & & \\
\hline MARKET VARIANCE CHANGE & & $\begin{array}{l}0.2826^{* * *} \\
(5.37)\end{array}$ & $\begin{array}{l}0.3314^{* * *} \\
(6.94)\end{array}$ & $\begin{array}{l}0.4221^{* * *} \\
(7.15)\end{array}$ \\
\hline Constant & $\begin{array}{l}-0.0398 \\
(-0.32)\end{array}$ & $\begin{array}{l}0.2327^{* * *} \\
(3.78)\end{array}$ & $\begin{array}{l}0.2313^{* *} \\
(2.56)\end{array}$ & $\begin{array}{l}0.2159^{* *} \\
(2.35)\end{array}$ \\
\hline Adjusted R squared & 0.2302 & 0.684 & 0.6397 & 0.5944 \\
\hline Observations & 1356 & 1356 & 1356 & 1356 \\
\hline
\end{tabular}

*Significant at $10 \%$; ${ }^{* *}$ Significant at $5 \%$; ${ }^{* *}$ Significant at $1 \%$.

Ordinary least squares regressions for a dataset of 1356 annual general meeting (AGM) dates of Italian companies in the period 1997-2004. In this sample, there are 465 approval AGMs that approved a repurchase program and 891 non-approval AGMs. Data for the AGM dates are obtained from Factiva and from companies' annual reports. Data for the other variables used in the regressions are obtained from Thomson Datastream and from the website of the Italian stock exchange (www.borsaitaliana.it). The dependent variables SPREAD CHANGE and VARIANCE CHANGE are the logarithm of one plus the relative changes, around AGMs, in daily bid-ask spread and daily return variance, respectively. APPROVAL AGM is a dummy that equals one for approval AGMs. VOLUME CHANGE, PRICE CHANGE, LONG TERM VARIANCE CHANGE, MARKET SPREAD CHANGE, and MARKET VARIANCE CHANGE are computed as the logarithm of one plus the relative changes around the AGM in daily trading volume, daily closing price, long-term return variance, value-weighted market daily bid-ask spread, and value-weighted market daily return variance, respectively. The long-term variance is calculated using two-week, three-week, or four-week log-returns. IPO is a dummy that equals one if part of the first year of trading (253 trading days) of the stock is in the interval of calculation of relative changes. All variables are described in detail in Table 2 . Two sets of dummy variables, one with seven year dummies and one with six industry dummies, are always included among the independent variables. Results for these dummies are not reported. Reported $t$-statistics (in parentheses) are adjusted for heteroskedasticity and serial correlation.

effect of repurchase approvals in line with Hypothesis 2a, but the results are mixed and overall only weakly statistically significant. ${ }^{37}$

\section{Robustness checks}

This section examines the robustness of our results to variations in our research design. We consider several extensions and variations including the use of fixed effects and simultaneous-equations methods. We also look at the effect of outliers, structural changes, and variation in the event window (the interval over which we compute changes in the variables around AGMs). We begin by considering an alternative measure for liquidity, namely, trading volume, and then examining alternative ways of capturing own-stock transactions dealing with sales and purchases of shares separately.

\subsection{Trading volume}

We consider trading volume (number of shares traded over number of outstanding shares) as an alternative liquidity measure. Specifically, we repeat all the empirical analyses replacing bid-ask spread with trading volume. In the multivariate regressions (not reported in the paper), we consider appropriate sets of explanatory variables for trading volume based on the existing literature. Unfortunately, we cannot draw clear conclusions based on the findings for trading volume. When the average trading volume is regressed on either TRADING or DUMMY TRADING and other explanatory variables, the coefficients on TRADING and

37 An approval at the AGM (i.e., a change in the APPROVAL variable from zero to one) reduces SPREAD CHANGE by 0.1 standard deviations and VARIANCE CHANGE by 0.03 standard deviations (based on the standard deviations shown in Table 7). 
Table 10

Regressions for sub-samples of a dataset of annual general meetings (AGMs) comprising both approval and non-approval AGMs.

\begin{tabular}{|c|c|c|c|}
\hline Variable & Observations & Coefficient of APPROVAL AGM & $p$-value of the coefficient \\
\hline \multicolumn{4}{|l|}{ SPREAD CHANGE } \\
\hline Low pre-AGM spread & 310 & -0.0427 & 0.186 \\
\hline Medium pre-AGM spread & 310 & 0.0243 & 0.501 \\
\hline High pre-AGM spread & 310 & -0.1641 & 0.02 \\
\hline \multicolumn{4}{|l|}{ VARIANCE CHANGE } \\
\hline \multicolumn{4}{|c|}{ (LONG TERM VARIANCE CHANGE using } \\
\hline \multicolumn{4}{|l|}{ 2-week returns) } \\
\hline Low pre-AGM variance & 310 & -0.0603 & 0.38 \\
\hline Medium pre-AGM variance & 310 & -0.0205 & 0.694 \\
\hline High pre-AGM variance & 310 & -0.0656 & 0.177 \\
\hline \multicolumn{4}{|l|}{ VARIANCE CHANGE } \\
\hline \multicolumn{4}{|c|}{ (LONG TERM VARIANCE CHANGE using } \\
\hline \multicolumn{4}{|l|}{ 3-week returns) } \\
\hline Low pre-AGM variance & 310 & -0.1171 & 0.065 \\
\hline Medium pre-AGM variance & 310 & -0.009 & 0.873 \\
\hline High pre-AGM variance & 310 & -0.0238 & 0.632 \\
\hline \multicolumn{4}{|l|}{ VARIANCE CHANGE } \\
\hline \multicolumn{4}{|c|}{ (LONG TERM VARIANCE CHANGE using } \\
\hline \multicolumn{4}{|l|}{ 4-week returns) } \\
\hline Low pre-AGM variance & 310 & -0.0754 & 0.319 \\
\hline Medium pre-AGM variance & 310 & 0.0139 & 0.801 \\
\hline High pre-AGM variance & 310 & -0.0505 & 0.319 \\
\hline
\end{tabular}

Ordinary least squares regressions for sub-samples of a dataset of 1356 annual general meeting (AGM) dates of Italian companies in the period 1997-2004. In this dataset, there are 465 approval AGMs that approved a repurchase program and 891 non-approval AGMs. Data for the AGM dates are obtained from Factiva and from companies' annual reports. Data for the other variables used in the regressions are obtained from Thomson Datastream and from the website of the Italian stock exchange (www.borsaitaliana.it). The dependent variables for the regressions are SPREAD CHANGE and VARIANCE CHANGE, which are the logarithm of one plus the relative changes around AGMs in daily bid-ask spread and daily return variance, respectively. For each of these two variables, regressions are run on datasets with 310 observations each comprising a sub-sample of 155 approval AGMs and a matching sub-sample of 155 non-approval AGMs. In particular, three sub-samples of equal size with low, medium, and high values of either bid-ask spread (for SPREAD CHANGE) or return variance (for VARIANCE CHANGE) in the preAGM period (from trading days - 120 to -11 , with trading day 0 being the AGM date) are obtained from the overall sample of 465 approval AGMs. The matching sub-samples are constructed by finding for each approval AGM a matching non-approval AGM having the most similar pre-AGM value of either bid-ask spread (for SPREAD CHANGE) or return variance (for VARIANCE CHANGE) and occurring in the same fiscal year. The explanatory variables for SPREAD CHANGE are APPROVAL AGM, VARIANCE CHANGE, IPO, VOLUME CHANGE, PRICE CHANGE, MARKET SPREAD CHANGE, a set of seven year dummies, and a set of six industry dummies. The explanatory variables for VARIANCE CHANGE are APPROVAL AGM, SPREAD CHANGE, IPO, VOLUME CHANGE, PRICE CHANGE, LONG TERM VARIANCE CHANGE (computed using two-week, three-week, or four-week log-returns), MARKET VARIANCE CHANGE, a set of seven year dummies, and a set of six industry dummies. APPROVAL AGM is a dummy that equals one for approval AGMs. VOLUME CHANGE, PRICE CHANGE, LONG TERM VARIANCE CHANGE, MARKET SPREAD CHANGE, and MARKET VARIANCE CHANGE are the logarithm of one plus the relative changes around AGMs in daily trading volume, daily closing price, long-term return variance, value-weighted market daily bid-ask spread, and value-weighted market daily return variance respectively. The long-term variance is calculated using two-week, three-week, or four-week log-returns. IPO is a dummy that equals one if part of the first year of trading (253 trading days) of the stock is comprised in the interval of calculation of relative changes. All variables are described in detail in Table 2. Only the coefficients for APPROVAL AGM and its $p$-values, adjusted for heteroskedasticity and serial correlation, are reported.

DUMMY TRADING are positive and statistically significant in the OLS models. However, the coefficients on these variables are normally insignificant in the GMM models. It is worth mentioning that the findings of the GMM regressions are not reliable given that the Sargan and Hansen tests for over-identifying restrictions are normally rejected. In the regression analysis of volume changes around repurchase AGMs, the coefficient on APPROVAL AGM is positive but statistically insignificant.

The overall absence of statistically significant results for trading volume may be explained by the fact that, in most cases, trading in own shares is not a large part of total trading activity.

\subsection{Separate analysis of sales and purchases of own shares}

In the previous analysis we measure trading in own stocks as the total number of shares transacted in terms of the sum of all shares bought and sold by the company. As an alternative, we might focus on purchases only or sales only. When we examine sales and purchases separately, we find that sales account for a substantial $35.22 \%$ of the total number of shares transacted: while the mean of the TRADING variable is 0.006233 taking purchases and sales together, it is 0.004038 for purchases only and 0.002195 for sales only. However, in a given firm-year, sales almost always occur alongside purchases. In the sample of 788 firm-year observations used in the first part of our analysis (see Table 3 for descriptive statistics) there are only 18 firm-year observations with sales only (and no purchases).

Re-estimating our regressions with the (DUMMY) TRADING variables capturing purchases only, our results remain qualitatively unchanged.

Further, we test whether the effect of own-shares purchases on stock liquidity and volatility is significantly different from that of sales on the same variables. We create a variable that measures the share of sales in total transactions in own shares. We reestimate our regressions with this new variable added and find that the coefficients on the variable are always statistically 


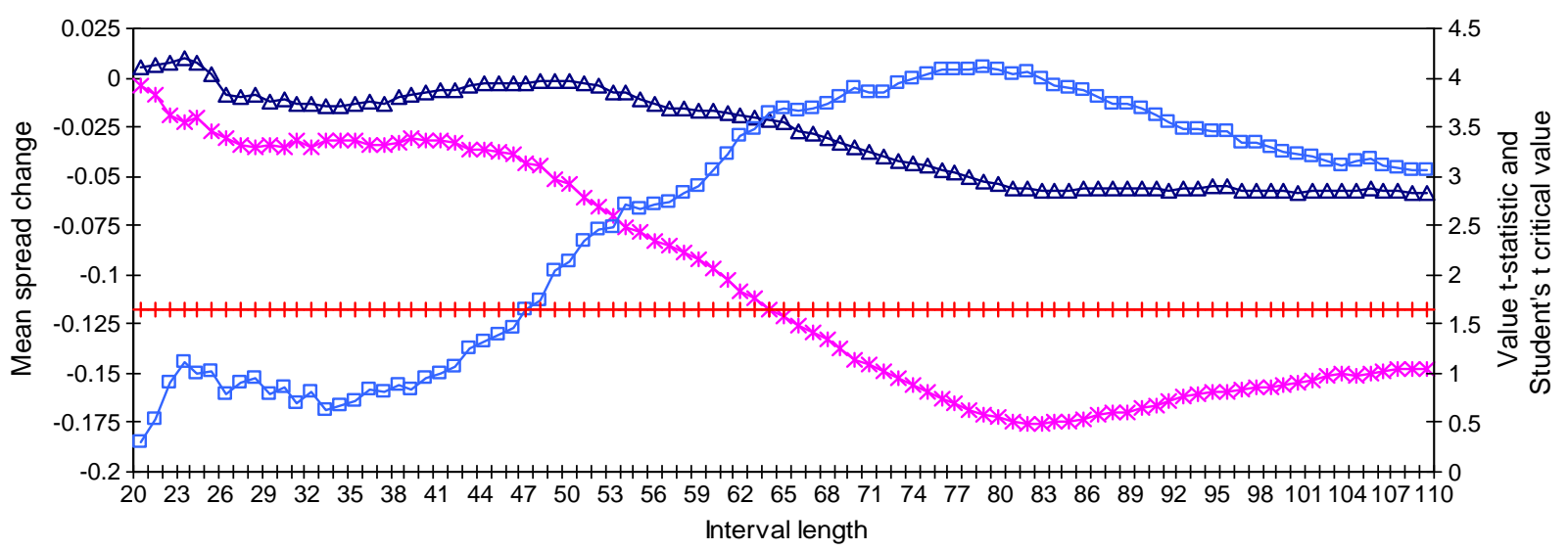

$$
\begin{aligned}
& \rightarrow \text { Mean spread change for repurchase AGMs (AGMs that approved repurchase programs) } \\
& \triangle \text { - Mean spread change for non-repurchase AGMs (AGMs that did not approve repurchase programs) } \\
& \square-\text { Test statistic for mean spread change for non-repurchase AGMs vs mean spread change for repurchase AGMs } \\
& \square \text { Student's t critical value }(0.95) \text { for test statistic }
\end{aligned}
$$

Fig. 1. Spread change computed using several intervals around repurchase and non-repurchase annual general meetings (AGMs). The length of the interval of calculation for spread changes (horizontal axis) ranges from 20 to 110 trading days. If the AGM date is day 0 and the length of the interval is 20 , spread changes are computed using average spread values in the periods -30 to -11 (pre-AGM period) and +11 to +30 (post-AGM period). For an interval of 110 days, the preAGM period ranges from -120 to -11 and the post-AGM period ranges from +11 to +120 . The first vertical axis (on the left) comprises values for spread changes. The second vertical axis comprises values for a Student's t-test on the difference between mean spread change for non-repurchase AGMs and mean spread change for repurchase AGMs. This axis also reports the upper critical value of the test at the $10 \%$ significance level.

insignificant. Similar conclusions can be drawn if a dummy that identifies firm-years with sales is added to the regressions that comprise the variable DUMMY TRADING.

\subsection{Fixed-effects estimation}

In Section 5.2 we report the results of several OLS regressions for the dependent variables SPREAD CHANGE and VARIANCE CHANGE. We repeat these estimations using the fixed effects (FE) method to resolve any omitted variable bias potentially afflicting the OLS estimates. Suppose the approval of a repurchase program is a function of certain firm or stock characteristics that also affect the dependent variables and other control variables. Although our models control for a range of observable variables, some firm- or stock-specific variables may have been omitted, possibly because they are unobservable. If the omitted variables are correlated with the explanatory variable of interest, in our case the APPROVAL AGM dummy, its parameter estimate will be biased. The FE estimator resolves this problem because it uses time-demeaned data removing firm- or stock-specific effects from the error term by focusing on variations in the variables around their long-term means.

The results for these FE estimations are qualitatively similar to those from the OLS estimations.

\subsection{Simultaneity bias}

The literature cited in Section 4.1 on the determinants of the variables bid-ask spread and return variance shows that these two variables are likely to be jointly determined in that return variance is an explanatory variable of bid-ask spread, which in turn is a determinant of return variance. This implies that the variables SPREAD (CHANGE) and VARIANCE (CHANGE) should be estimated in the context of a system of two simultaneous equations. By ignoring the simultaneity issue, our multivariate results above may be biased and inconsistent. We repeat our multivariate estimations assuming that the variables SPREAD CHANGE, VARIANCE CHANGE, SPREAD, and VARIANCE are endogenous explanatory variables. More specifically, we instrument each of these variables with a set of instruments that is given by all their explanatory variables, used in the multivariate analyses, which are excluded from the equation to be estimated. For example, in the equation with SPREAD CHANGE as dependent variable, we assume that VARIANCE CHANGE is endogenous and we use the variables LONG TERM VARIANCE CHANGE and MARKET VARIANCE CHANGE as instruments. The results of the new set of multivariate analyses are qualitatively not different from the results of the original estimations.

\subsection{Structural changes}

Both bid-ask spread and return variance are potentially sensitive to structural changes in market microstructure characteristics. A major modification in the institutional features of the Italian stock market took place in April 2001. Among other things, a non-negligible number of securities started trading in a new specialist-based segment of the exchange, shifting from a purely electronic auction market. There is some evidence that this shift caused a sizable decrease in spread (Frino et al., 


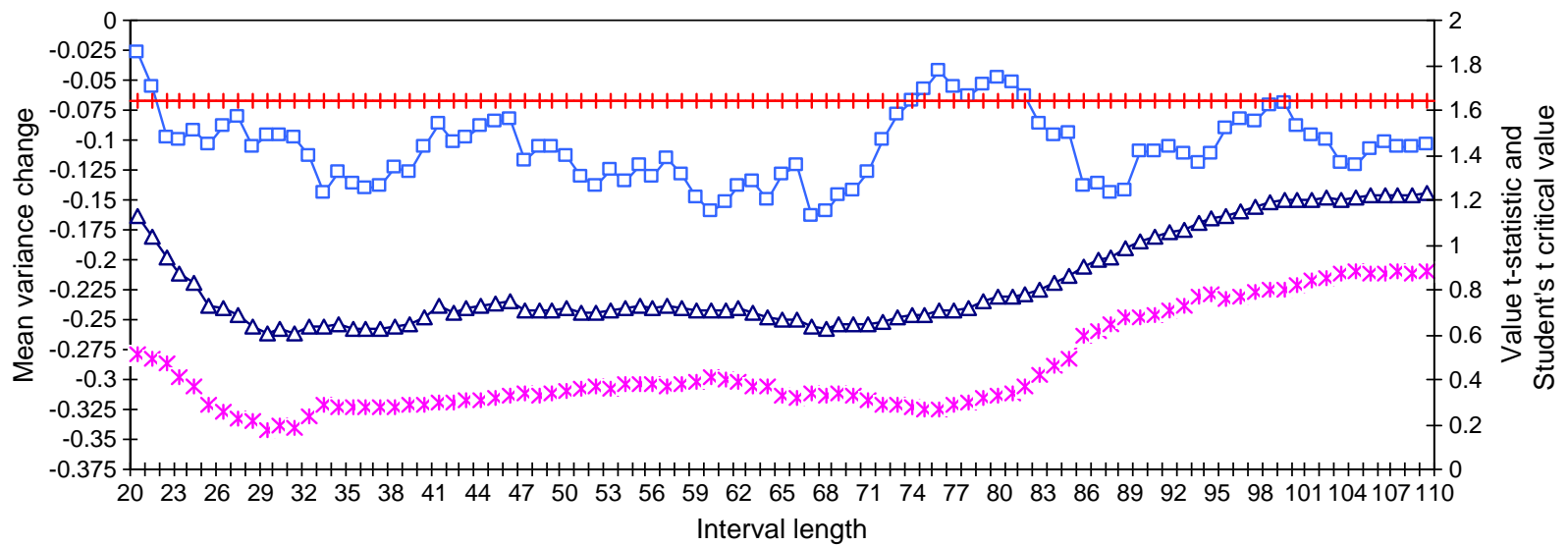

$$
\begin{aligned}
& - \text { - Mean variance change for repurchase AGMs (AGMs that approved repurchase programs) } \\
& -\square-\text { Mean variance change for non-repurchase AGMs (AGMs that did not approve repurchase programs) } \\
& -\square-\text { Test statistic for mean variance change for non-repurchase AGMs vs mean variance change for repurchase AGMs } \\
& \square \text { Student's } t \text { critical value (0.95) for test statistic }
\end{aligned}
$$

Fig. 2. Variance change computed using several intervals around repurchase and non-repurchase annual general meetings (AGMs). The length of the interval of calculation of variance changes (horizontal axis) ranges from 20 to 110 trading days. If the AGM date is day 0 and the length of the interval is 20 , variance changes are computed using variance values in the periods -30 to -11 (pre-AGM period) and +11 to +30 (post-AGM period). For an interval of 110 days, the pre-AGM period ranges from -120 to -11 and the post-AGM period ranges from +11 to +120 . The first vertical axis (on the left) comprises values for variance changes. The second vertical axis comprises values for a Student's $t$-test on the difference between mean variance change for non-repurchase AGMs and mean variance change for repurchase AGMs. This axis also reports the upper critical value of the test at the $10 \%$ significance level.

2008). To eliminate potentially contaminated observations we create a reduced sample of AGM dates free from all the AGMs occurring in 2001. We also exclude firm-year observations relative to the fiscal year 2001 from the original sample of data on trading in own shares. These new datasets are then used to re-estimate the multivariate models presented in Sections 5.1 and 5.2. The findings of the new estimations on the reduced datasets are qualitatively the same as those on the complete datasets.

\subsection{Outliers}

We verify whether our multivariate findings are driven by outliers. We winsorize all the non-binary variables at $0.5 \%$ and $99.5 \%$ of the distribution. Re-estimating the regressions of Sections 5.1 and 5.2 using the winsorized variables, we obtain results that are not qualitatively different from those of the original regressions.

\subsection{Variation in the event window}

The main objective of this paper is to investigate the impact of repurchases on bid-ask spread and return variance over fairly long time intervals. For this reason, the variables SPREAD CHANGE and VARIANCE CHANGE are computed as the changes in the averages from the 110 trading days in the pre-AGM period to the 110 days in the post-AGM period, specifically using as the event windows (day -120 , day -10 ) and (day 10, day 120 ) relative to the AGM day (day 0 ). The choice of these intervals is somewhat arbitrary, and there is a risk that the empirical findings are highly sensitive to this choice. We repeat some of the univariate analyses using shorter intervals. Specifically, we compute the variables SPREAD CHANGE and VARIANCE CHANGE using intervals ranging from 20 to 110 trading days in the pre- and in the post-AGM periods. For instance, using an interval of 20 days, the preAGM window is (day -30 , day -11 ) relative to day 0 , the AGM day, and the post-AGM window is (day +11 , day +30 ).

Fig. 1 and Fig. 2 summarize our findings using the new intervals for SPREAD CHANGE and VARIANCE CHANGE respectively. Mean values for the two variables are always lower (indicating greater reductions in spread and variance) for approval AGMs than for non-approval AGMs. For intervals longer than 47 trading days, the difference in mean SPREAD CHANGE between approval and nonapproval AGMs is statistically significant at the $10 \%$ level. This confirms the conclusion of the original univariate analysis that approvals of repurchase programs result in a significant reduction in spread over relatively long intervals. Differences in mean VARIANCE CHANGE between approval and non-approval AGMs are in most cases not statistically significant, confirming our earlier univariate results.

\section{Conclusions}

In this paper we study whether companies can increase the liquidity and stabilize the price of their stocks by trading in their own stocks, a question that is unresolved and has been largely ignored in the existing literature. Trades in own shares may support market 
liquidity in periods in which it is weak. Also, if trades are directed to counterbalance heavy trading in a particular direction, they may lead to price stabilization. It is likely that such price stabilization activities would be mainly utilized in response to a falling price.

We analyze a sample of transactions in own shares by Italian companies and an Italian dataset of share repurchase approvals in the period 1997-2004. Analyzing both datasets using a range of methods we find that trading in own shares has a statistically significant impact on liquidity in terms of a reduction in spread. This impact is stronger for stocks that were previously illiquid (high spread). Our findings also suggest that by trading their own stocks companies can successfully reduce short-term price instability, thereby smoothing price discovery. Controlling for long-term fundamental variance, there is a statistically significant reduction in short-term variance associated with own-share transactions.

We also find that trading volume is not significantly affected by company trading. This is possibly due to the small size of company trading relative to the overall volume of trading in a stock.

The findings of this study have important policy implications for Italy and beyond. Fried (2005) suggests that regulators should pay more attention to the drawbacks of repurchases, such as the potential for managers to use inside information opportunistically to maximize their wealth at the expense of investors. The same argument applies to company sales of treasury shares. In light of these arguments, regulators may be tempted to restrict the freedom of companies to trade their own stock. However, companies in most countries including the U.S. already face much greater obstacles than their Italian counterparts, particularly with regard to open-market sales of treasury shares. Our results suggest that restrictions on company trading may not only limit opportunistic behavior by insiders but also bar companies from pursuing the beneficial effects of trading in terms of reductions in spreads and volatility, resulting in lower transactions costs and costs of equity capital and higher firm value and shareholder wealth. Regulators need to be aware of the potential benefits of own-stock trading identified in this study and balance these benefits against any downside of such trading before curtailing the freedom of companies to trade their own stock.

\section{Acknowledgements}

We thank an anonymous referee, Michael Brennan, Paul Brockman, Patricia Chelley-Steeley, Dennis Chung, Johan H. von Eije, Mara Faccio, Bill Megginson, Ajai Singh, Norman Strong, Jialin Yu, and seminar participants at Warwick Business School, the European Financial Management 2007 Annual Meeting in Vienna, and the Financial Management 2007 Annual Meeting in Orlando for helpful comments. The authors are solely responsible for the remaining errors in the paper.

\section{References}

Ahn, H., Cao, C., Choe, H., 2001. Share repurchase tender offers and bid-ask spreads. J. Bank. Finance 25, $445-478$.

Amihud, Y., Mendelson, H., 1986. Asset pricing and the bid-ask spread. J. Fin. Econ. 17, 223-249.

Amihud, Y., Mendelson, H., 1987. Trading mechanisms and stock returns: an empirical investigation. J. Finance 42, $533-553$.

Anand, A., Tanggaard, C., Weaver, D.G., 2009. Paying for market quality. J. Financ. Quant. Anal. 44, 1427-1457.

Arellano, M., Bond, S., 1991. Some tests of specification for panel data: Monte Carlo evidence and an application to employment equations. Rev. Econ. Stud. 58, 277-297.

Arellano, M., Bover, O., 1995. Another look at the instrumental variables estimation of error-component models. J. Econ. 68, $29-51$.

Autore, D.M., Kumar, R., Shome, D.K., 2008. The revival of shelf-registered corporate equity offerings. J. Corp. Fin. 14, 32-50.

Autore, D.M., I. Hutton, and T. Kovacs, 2011. Accelerated equity offers and firm quality. European Financial Management. 17, 835-859

Bagehot, W., 1971. The only game in town. J. Fin. Anal. 27, 12-14.

Baker, H.K., Gallagher, P.L., Morgan, K.F., 1981. Management's view on stock repurchase programs. J. Financ. Res. 4, $233-247$.

Banyi, M., Dyl, E., Kahle, K.M., 2008. Errors in estimating share repurchases. J. Corp. Fin. 14, 460-474.

Barclay, M.J., Smith, C.W., 1988. Corporate payout policy. Cash dividends versus open-market repurchases. J. Financ. Econ. 22, 61-82.

Baum, C., Schaffer, M., Stillman, S., 2003. Instrumental variables and GMM: estimation and testing. Stata Journal 3, 1-31.

Beny, L.N., 2005. Do insider trading laws matter? Some preliminary comparative evidence. Am. Law Econ. Rev. 7, $144-183$.

Bethel, J.E., Krigman, L., 2008. Managing the costs of issuing common equity: the role of registration choice. Q. J. Finance Acc. $47,57-85$.

Black, F., 1986. Noise. J. Finance 41, 529-543.

Blundell, R., Bond, S., 1998. Initial conditions and moment restrictions in dynamic panel data models. J. Econ. 87, 11-143.

Bond, S.R., 2002. Dynamic panel data models: a guide to micro data methods and practice. Port. Econ. J. 1, 141-162.

Branch, B., Freed, W., 1977. Bid-ask spreads on the AMEX and the Big Board. J. Finance 32, 159-163.

Brav, A., Graham, J.R., Harvey, C.R., Michaely, R., 2005. Payout policy in the 21st century. J. Financ. Econ. 77, 483-527.

Brockman, P., Chung, D.Y., 2001. Managerial timing and corporate liquidity: evidence from actual share repurchases. J. Financ. Econ. 61, 417-448.

Brockman, P., Chung, D.Y., 2002. Commonality in liquidity: evidence from an order-driven market structure. J. Financ. Res. 25, 521-539.

Brockman, P., Howe, J., Mortal, S., 2008. Stock market liquidity and the decision to repurchase. J. Corp. Fin. 14, 446-459.

Charitou, A., Panayides, M., 2009. Market making in international capital markets: challenges and benefits of its implementation in emerging markets. International Journal of Managerial Finance: Special Issue on International Market Microstructure, 5, pp. 50-80.

Chordia, T., Roll, R., Subrahmanyan, A., 2000. Commonality in liquidity. J. Financ. Econ. 56, 3-28.

Cook, D.O., Krigman, L., Leach, J.C., 2003. An analysis of SEC guidelines for executing open market repurchases. J. Bus. 76, $289-315$.

Cook, D.O., Krigman, L., Leach, J.C., 2004. On the timing and execution of open market repurchases. Rev. Financ. Stud. 17, 463-498.

De Cesari, A., Espenlaub, S., Khurshed, A., Simkovic, M., 2011. The effects of ownership and stock liquidity on the timing of repurchase transactions. Unpublished working paper.

Demsetz, H., 1968. The cost of transacting. Q. J. Econ. 82, 33-53.

Du, J., Wei, S., 2004. Does insider trading raise market volatility? Econ. J. 114, 916-942.

Duffee, G.R., 1995. Stock returns and volatility: a firm-level analysis. J. Financ. Econ. 37, 399-420.

Eberhart, A.C., Siddique, A.R., 2004. Why are stock buyback announcements good news? Unpublished working paper.

von Eije, H., Megginson, W., 2008. Dividends and share repurchases in the European Union. J. Financ. Econ. 89, 347-374.

Fishman, M.J., Hagerty, K.M., 1992. Insider trading and the efficiency of stock prices. RAND J. Econ. 23, $106-122$.

Franz, D.R., Rao, R.P., Tripathy, N., 1995. Informed trading risk and bid-ask spread changes around open market stock repurchases in the Nasdaq market. J. Financ. Res. 18, 311-327.

French, K.R., Roll, R., 1986. Stock return variances. The arrival of information and the reaction of traders. J. Financ. Econ. 17, 5-26. 
Fried, J.M., 2005. Informed trading and false signalling with open market repurchases. Calif. Law Rev. 93, 1326-1386.

Frino, A., Gerace, D., Lepone, A., 2008. Liquidity in auction and specialist market structures: evidence from the Italian bourse. J. Bank. Finance 32, 2581-2588.

Gallant, A.R., Rossi, P.E., Tauchen, G., 1992. Stock prices and volume. Rev. Financ. Stud. 5, 199-242.

Gao, X., Ritter, J.R., 2010. The marketing of seasoned equity offerings. J. Financ. Econ. 97, 33-52.

Glosten, L.R., Milgrom, P.R., 1985. Bid, ask, and transaction prices in a specialist market with heterogeneously informed traders. J. Financ. Econ. 14, 71-100.

Goyal, A., Santa-Clara, P., 2003. Idiosyncratic risk matters. J. Finance 58, 975-1007.

Grullon, G., Michaely, R., 2002. Dividends, share repurchases, and the substitution hypothesis. J. Finance 57, 1649-1684.

Harris, M., Raviv, A., 1993. Differences of opinion make a horse race. Rev. Financ. Stud. 6, 473-506.

Hong, H.G., Wang, J., Yu, J., 2008. Firms as buyers of last resort. J. Financ. Econ. 88, 114-119.

Jagannathan, M., Stephens, C.P., Weisbach, M.S., 2000. Financial flexibility and the choice between dividends and stock repurchases. J. Financ. Econ. 57, 355-384.

Jain, P.K., 2003. Institutional design and liquidity at stock exchanges around the world. Unpublished working paper.

Karpoff, J.M., 1987. The relation between price changes and trading volume: a survey. J. Financ. Quant. Anal. 22, $109-126$.

Kaul, G., Nimalendran, M., 1990. Price reversals: bid-ask errors or market overreaction? J. Financ. Econ. 28, 67-93.

Kim, J., 2005. Cross-sectional differences in the liquidity effects of open market share repurchases. J. Econ. Finance 29, 1-31.

Koski, J.L., 1998. Measurement effects and the variance of returns after stock splits and stock dividends. Rev. Financ. Stud. 11, $143-162$.

La Porta, R., Lopez-de-Silanes, F., Shleifer, A., Vishny, R.W., 1998. Law and finance. J. Polit. Econ. 106, 1113-1155.

Lamourex, C.G., Lastrapes, W.D., 1990. Heteroscedasticity in stock return data: volume versus GARCH effects. J. Finance 45, 221-229.

Lee, B., Rui, O.M., 2002. The dynamic relationship between stock returns and trading volume: domestic and cross-country evidence. J. Bank. Finance 26, 51-78.

Leland, H.E., 1992. Insider trading: should it be prohibited? J. Polit. Econ. 100, 859-887.

Lemmon, M.L., Roberts, M.C., Zender, J.F., 2008. Back to the beginning: persistence and the cross-section of corporate capital structure. J. Finance 63, 1-37.

Levy, H., 1978. Equilibrium in an imperfect market: a constraint in the number of securities in the portfolio. Am. Econ. Rev. 68, $643-658$.

Menkveld, A.J., Wang, T., 2011. How do designated market makers create value for small-caps?Unpublished working paper.

Merton, R.C., 1987. A simple model of capital market equilibrium with incomplete information. J. Finance 42, 483-510.

Miller, J.M., McConnell, J.J., 1995. Open-market share repurchase programs and bid-ask spreads on the NYSE: implications for corporate payout policy. J. Financ. Quant. Anal. 30, 365-382.

Moehrle, S.R., Reynolds-Moehrle, J.A., Stuerke, P.S., 2004. Shelf registered securities: is it time to re-evaluate the process? Res. Acc. Regul. $17,3-24$.

Mura, R., 2007. Firm performance: do non-executive directors have minds of their own? Evidence from UK panel data. Financ. Manage. $37,81-112$.

Myers, S., Majluf, N.S., 1984. Corporate financing and investment decisions when firms have information that investors do not have. J. Financ. Econ. 13, 187-221.

Nayar, N., Singh, A.K., Zebedee, A.A., 2008. Share repurchase offers and liquidity: an examination of temporary and permanent effects. Financ. Manage. 37, $251-270$

Nimalendran, M., Petrella, G., 2003. Do 'thinly-traded' stocks benefit from specialist intervention? J. Bank. Finance 27, $1823-1854$.

O'Hara, M., 2003. Presidential address: liquidity and price discovery. J. Finance 58, 1335-1354.

OICV-IOSCO, 2004. Report on 'stock repurchase programs'. International Organization of Securities Commissions.

Perotti, P., Rindi, B., 2010. Market makers as information providers: the natural experiment of STAR. J. Empirical Finance 17, $895-917$.

Pozzo, B., 2003. L'acquisto di azioni proprie. La storia di un problema in un'analisi di diritto comparato. Dott. A. Giuffre' Editore, Milano, Italy.

Roodman, D., 2006. How to do xtabond2: an introduction to 'difference' and 'system' GMM in Stata. Unpublished working paper, Centre for Global Development.

Schwartz, R.A., Francioni, R., 2004. Equity markets in action. The Fundamentals of Liquidity, Market Structure \& Trading. John Wiley \& Sons, New Jersey.

Schwert, G.W., 1989. Why does stock market volatility change over time? J. Finance 44, 1115-1153.

Shalen, C.T., 1993. Volume, volatility, and the dispersion of beliefs. Rev. Financ. Stud. 6, 405-434.

Singh, A.K., Zaman, M.R., Krisnhamurti, C., 1994. Liquidity changes associated with open market repurchases. Financ. Manage. $23,47-55$.

Skinner, D.J., 2008. The evolving relation between earnings, dividends, and stock repurchases. J. Financ. Econ. 87, $582-609$.

Stephens, C.P., Weisbach, M.S., 1998. Actual share reacquisitions in open-market repurchase programs. J. Finance 53, $313-333$.

Stoll, H.R., 1978. The pricing of security dealer service: an empirical study of Nasdaq stocks. J. Finance 33, 1153-1172.

Stoll, H.R., 2000. Friction. J. Finance 55, 1479-1514.

Stoll, H.R., Whaley, R.E., 1990. Stock market structure and volatility. Rev. Financ. Stud. 3, 37-71.

Tinic, S.M., 1972. The economics of liquidity services. O. J. Econ. 86, 79-93.

Venkataraman, K., Waisburd, A.C., 2007. The value of the designated market maker. J. Financ. Quant. Anal. 42, 735-758.

Wang, G.H.K., Yau, J., 2000. Trading volume, bid-ask spread, and price volatility in futures markets. J. Futur. Mark. 20, $943-970$.

Wansley, J.W., Lane, W.R., Sarkar, S., 1989. Management's view on share repurchase and tender offer premiums. Financ. Manage. 18, 97-110.

Wiggins, J.B., 1994. Open market stock repurchase programs and liquidity. J. Financ. Res. 17, 217-229.

Wooldridge, J.M., 2002. Econometric Analysis of Cross Section and Panel Data. the MIT Press, Massachusetts, Cambridge. 